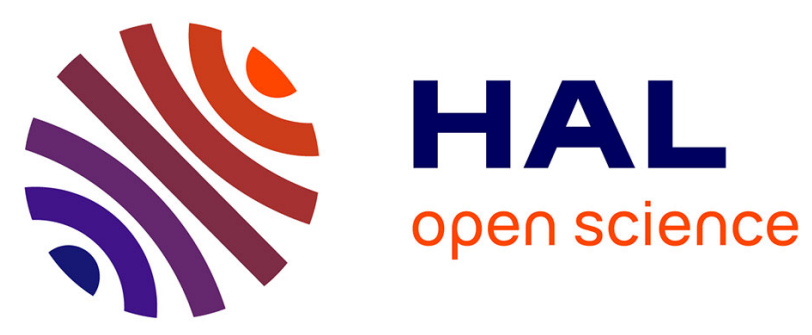

\title{
Polyoxothiometalate-Derivatized Silicon Photocathodes for Sunlight-Driven Hydrogen Evolution Reaction
}

Dong Fu, Bruno Fabre, Gabriel Loget, Cristelle Mériadec, Soraya

Ababou-Girard, Emmanuel Cadot, Nathalie Leclerc-Laronze, Jérôme Marrot, Quentin de Ponfilly

\section{To cite this version:}

Dong Fu, Bruno Fabre, Gabriel Loget, Cristelle Mériadec, Soraya Ababou-Girard, et al.. Polyoxothiometalate-Derivatized Silicon Photocathodes for Sunlight-Driven Hydrogen Evolution Reaction. ACS Omega, 2018, 3 (10), pp.13837-13849. 10.1021/acsomega.8b01734 . hal-01935236

HAL Id: hal-01935236

https://hal-univ-rennes1.archives-ouvertes.fr/hal-01935236

Submitted on 17 Jul 2019

HAL is a multi-disciplinary open access archive for the deposit and dissemination of scientific research documents, whether they are published or not. The documents may come from teaching and research institutions in France or abroad, or from public or private research centers.
L'archive ouverte pluridisciplinaire HAL, est destinée au dépôt et à la diffusion de documents scientifiques de niveau recherche, publiés ou non, émanant des établissements d'enseignement et de recherche français ou étrangers, des laboratoires publics ou privés. 


\title{
Polyoxothiometalate-Derivatized Silicon Photocathodes for Sunlight-Driven Hydrogen Evolution Reaction
}

\author{
Dong Fu, ${ }^{\dagger}$ Bruno Fabre, ${ }^{* \dagger}{ }^{\dagger}$ Gabriel Loget, ${ }^{\dagger}$ Cristelle Mériadec, ${ }^{\ddagger}$ Soraya Ababou-Girard, \\ Emmanuel Cadot, ${ }^{*}{ }^{\S}$ Nathalie Leclerc-Laronze, ${ }^{\S}$ Jérôme Marrot, $^{\S}$ and Quentin de Ponfilly ${ }^{\S}$ \\ †Université Rennes, CNRS, ISCR (Institut des Sciences Chimiques de Rennes)-UMR6226, F-35000 Rennes, France \\ ${ }^{\ddagger}$ Université Rennes, CNRS, IPR (Institut de Physique de Rennes)-UMR6251, F-35000 Rennes, France \\ ${ }^{\S}$ Institut Lavoisier de Versailles (UMR-CNRS 8180), UVSQ, Université Paris-Saclay, 45 Avenue de Etats-Unis, 78000 Versailles, \\ France
}

\section{Supporting Information}

\begin{abstract}
Silicon photocathodes coated with drop-casted $\left\{\mathrm{Mo}_{3} \mathrm{~S}_{4}\right\}$-based polyoxothiometalate assemblies are demonstrated to be effective for sunlight-driven hydrogen evolution reaction (HER) in acid conditions. These photocathodes are catalytically more efficient than that coated with the parent thiomolybdate incorporating an organic ligand, as supported by a higher onset potential and a lower overvoltage at $10 \mathrm{~mA}$ $\mathrm{cm}^{-2}$. At $\mathrm{pH} 7.3$, the trend is inversed and the beneficial effect of the polyoxometalate for the HER is not observed. Moreover, the polyoxothiometalate-modified photocathode
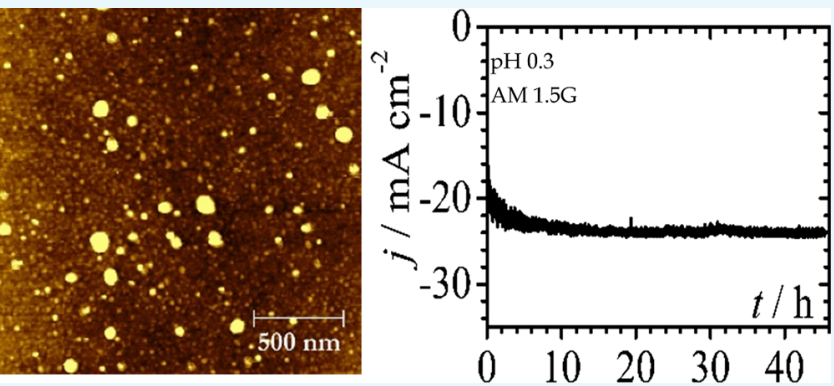
is found to be also more stable under acid conditions and can be operated at the light-limited catalytic current for more than $40 \mathrm{~h}$. Furthermore, X-ray photoelectron spectroscopy and atomic force microscopy measurements indicate that the cathodic polarization of both photocathodes leads to the release of a large amount of the deposited material into the electrolyte solution concomitantly with the formation of mixed valence species $\left\{\mathrm{Mo}(\mathrm{IV})_{3-x} \mathrm{Mo}(\mathrm{III})_{x} \mathrm{O}_{4-n} \mathrm{~S}_{n}\right\}^{(4-x)+}$ resulting from the replacement of $\mathrm{S}^{2-}$ sulfido ligands in the cluster by oxo $\mathrm{O}^{2-}$ groups; these combined effects are shown to be beneficial for the photoelectrocatalysis.
\end{abstract}

\section{INTRODUCTION}

The solar production of hydrogen from the photoelectrochemical reduction of protons has been essentially motivated by the actual growing need for sustainable sources of high-density energies. ${ }^{1-3}$ In this thematic area of solar fuels, silicon, with an energy gap of $1.12 \mathrm{eV},{ }^{4}$ is a very promising material to be used as a photocathode for the hydrogen evolution reaction (HER) because of its abundance, nontoxicity, and its tunable electronic properties. ${ }^{5,6}$ This material fails however to promote efficient multielectron transfers because of slow charge-transfer kinetics. ${ }^{6,7}$ Consequently, the deposition of pure metals (the archetypal example is platinum), ${ }^{6,8-10}$ metal oxides, ${ }^{11,12}$ or sulfides $^{13-22}$ onto silicon has been demonstrated to be an effective way to overcome intrinsic limitations of this semiconducting photocathode material for HER. ${ }^{23}$

In that context, silicon derivatized with molybdenum sulfidebased complexes, such as molybdenum disulfide and derivatives $\left(\mathrm{MoS}_{x}\right)^{15,16,18-22}$ or bioinspired cuboidal molecular clusters incorporating the $\left[\mathrm{Mo}_{3} \mathrm{~S}_{4}\right]^{4+}$ core, ${ }^{13,14}$ has been explored as a cheap and abundant alternative to $\mathrm{Pt}$ and the resulting photocathodes were found to exhibit high catalytic efficiency for sunlight-driven HER in acid electrolytes. Interestingly, $\left\{\mathrm{Mo}_{3} \mathrm{~S}_{4}\right\}$-based clusters offer rich coordination chemistry able to tune structural, redox, and chemical reactivity, thus giving the access to a wide range of combinations and properties. ${ }^{24-27}$ For instance, over the past decade, the development of synthetic strategies to access hybrid polyoxothiometalates including the $\left\{\mathrm{Mo}_{3} \mathrm{~S}_{4}\right\}$ core within a polyoxometalate (POM) framework has been engaged. ${ }^{28,29}$ The novelty of these systems lies on the combination at the molecular level of an identified active unit, that is, the $\left\{\mathrm{Mo}_{3} \mathrm{~S}_{4}\right\}$ core with a POM subunit behaving as electron reservoirs, that is, the POM framework. Because of their high nuclearity, POMs can undergo multielectron processes, making them ideal candidates for engineering complex multistep redox systems (from HER to $\mathrm{CO}_{2}$ reduction). ${ }^{30,31}$ Moreover, as POMs are highly functionalizable and generally robust enough to retain their structural integrity during the redox process, we anticipate that such systems coupled to silicon should provide effective and robust photocathodes for sunlight-driven HER. Furthermore, these photocathodes should exhibit enhanced long-term stability compared with that observed for electrodes integrating uncoupled $\left\{\mathrm{Mo}_{3} \mathrm{~S}_{4}\right\}$ coordination complexes. Indeed, it has

Received: July 21, 2018

Accepted: October 10, 2018

Published: October 22, 2018 
been reported that the latter ones were susceptible to be degraded in the presence of traces of $\mathrm{O}_{2}$ in the electrolytic solution. $^{13}$

Herein, silicon photocathodes decorated with $\left\{\mathrm{Mo}_{3} \mathrm{~S}_{4}\right\}$ based assemblies incorporating a polyoxotungstate $\left\{\mathrm{AsW}_{12} \mathrm{O}_{42}\right\}$ matrix are demonstrated to be effective for sunlight-driven HER under acid $\mathrm{pH}$ conditions. Such photocathodes showed a superior catalytic activity and a better robustness compared with photocathodes modified with $\left\{\mathrm{Mo}_{3} \mathrm{~S}_{4}\right\}$ clusters bearing an organic ligand such as a butylacetylacetonate ligand (noted acac-Bu, hereafter). Moreover, we here investigate the structural and chemical changes at these surfaces that occur during cathodic polarization, which were found to considerably improve the catalytic activity of the photocathodes as well as their stability.

\section{RESULTS AND DISCUSSION}

2.1. Characterization of the Molecular Precursors. 2.1.1. Molecular Structure of $\left[\mathrm{Mo}_{3} \mathrm{~S}_{4}(\mathrm{acac}-\mathrm{Bu})_{3}\left(\mathrm{H}_{2} \mathrm{O}\right)_{3}\right] \mathrm{Cl}$. $\mathrm{H}_{2} \mathrm{O}$. A summary of crystallographic data is given in Table $\mathrm{S} 1$. The single-crystal X-ray diffraction analysis of $\mathrm{Mo}_{3} \mathrm{~S}_{4}($ acac$\mathrm{Bu})$ revealed the discrete core $\left\{\mathrm{Mo}_{3} \mathrm{~S}_{4}\right\}$ coordinated to three butyl-acetylacetonate ligands (acac-Bu) (Figure 1). The

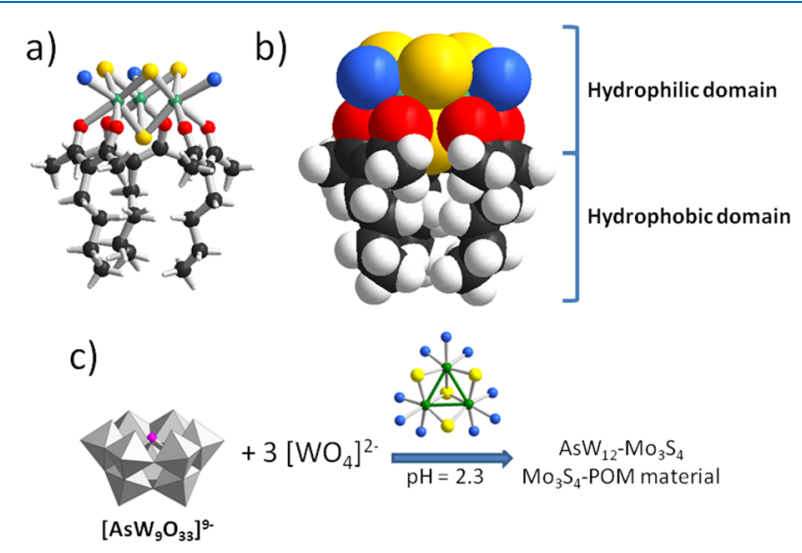

Figure 1. Ball and stick (a) and space-filling (b) structural representations of the $\left\{\mathrm{Mo}_{3} \mathrm{~S}_{4}\left(\mathrm{H}_{2} \mathrm{O}\right)_{3}(\mathrm{acac}-\mathrm{Bu})_{3}\right]^{+}$cationic unit (color code: green sphere $=$ Mo; yellow sphere $=S$; red sphere $=$ $\mathrm{O}$; blue sphere $=$ aquo ligand; black sphere $=\mathrm{C}$ and white sphere $=$ $\mathrm{H})$ showing the hydrophobic part clearly separated from the hydrophilic domain. (c) Scheme of synthesis applied for the preparation of the $\mathrm{Mo}_{3} \mathrm{~S}_{4}-\mathrm{POM}$ material resulting from the acidic condensation of tungstate $(\mathrm{pH}=2.3)$ on the trivacant precursor $\left[\mathrm{AsW}_{9} \mathrm{O}_{33}\right]^{9-}$ in the presence of the $\left[\mathrm{Mo}_{3} \mathrm{~S}_{4}\left(\mathrm{H}_{2} \mathrm{O}\right)_{9}\right]^{4+}$ aqua cluster.

coordination of the acac-Bu ligands takes place at the six equivalent equatorial sites of the Mo centers, whereas three aquo ligands were found to be attached to the Mo centers at the axial sites. Geometrical parameters (bond lengths and angle) within the coordination complex were found usual as those previously reported for the analogue $\left\{\mathrm{Mo}_{3} \mathrm{~S}_{4}\right\}$-containing complexes. $^{32}$ Nevertheless, the acac-Bu derivative of the triangular cluster $\left\{\mathrm{Mo}_{3} \mathrm{~S}_{4}\right\}$ exhibits a striking structural feature corresponding to the relative disposition of the three butyl alkyl chains that run in parallel along the $\mathrm{C}_{3}$ axis of the cluster (Figure 1b). Such structural characteristics allow distinguishing clearly the hydrophilic polar region, corresponding to the $\left\{\mathrm{Mo}_{3} \mathrm{~S}_{4}\left(\mathrm{H}_{2} \mathrm{O}\right)_{3}\right\}$ part, whereas the three butyl alkyl chains, arranged as pillars, delimit the hydrophobic domain. Then, amphiphilic behavior could be expected from such a cationic assembly which could be easily tuned depending on the length of the alkyl chains. Such studies are still ongoing progress.

2.1.2. $\mathrm{Mo}_{3} \mathrm{~S}_{4}-P O M$ Materials. The cationic cluster $\left\{\mathrm{Mo}_{3} \mathrm{~S}_{4}\right\}^{4+}$ exhibits a high propensity to be incorporated as a triangular unit within the polyoxometalate framework. This is an elegant way to associate covalently the catalytic $\left\{\mathrm{Mo}_{3} \mathrm{~S}_{4}\right\}$ component to an electron reservoir unit. The $\left\{\mathrm{Mo}_{3} \mathrm{~S}_{4}\right\}-\mathrm{POM}$ material was obtained as a mixed rubidium-sodium salt from condensation processes of three equivalents of $\mathrm{WO}_{4}{ }^{2-}$ tungstate ions on the trivacant precursor $\left[\mathrm{AsW}_{9} \mathrm{O}_{33}\right]^{9-}$ anion in the presence of $\left[\mathrm{Mo}_{3} \mathrm{~S}_{4}\left(\mathrm{H}_{2} \mathrm{O}\right)_{9}\right]^{4+}$ at $\mathrm{pH} 2.3$ (Figure 1c). The resulting solid retains the elemental composition $\mathrm{Rb}_{3} \mathrm{NaHAsW}_{12} \mathrm{Mo}_{3} \mathrm{~S}_{4}\left(\mathrm{H}_{2} \mathrm{O}\right)_{3} \mathrm{O}_{42} \cdot 14 \mathrm{H}_{2} \mathrm{O}$, consistent with the molecular unit $\left[\mathrm{AsW}_{12} \mathrm{Mo}_{3} \mathrm{~S}_{4}\left(\mathrm{H}_{2} \mathrm{O}\right)_{3} \mathrm{O}_{42}\right]^{5-}$. The solid, as well the resulting aqueous solution exhibit a dark-brown color, featuring the coordination of the $\left\{\mathrm{Mo}_{3} \mathrm{~S}_{4}\right\}$ core to the oxo group of the POM. ${ }^{29}$ Thus, the UV-vis spectrum (Figure S1) showed the characteristic weak absorption at $600 \mathrm{~nm}(\varepsilon=520$ $\mathrm{cm}^{-1} \mathrm{~mol}^{-1} \mathrm{~L}$ ) attributed to $\mathrm{d}-\mathrm{d}$ transitions of the $\mathrm{Mo}^{\mathrm{IV}}$ centers. Furthermore, the IR spectrum of $\mathrm{Mo}_{3} \mathrm{~S}_{4}-\mathrm{POM}$ contains the main absorption related to the polyoxotungstate framework. The vibration band at $950 \mathrm{~cm}^{-1}$ is attributed to the $\nu_{\text {as }}(\mathrm{W}=\mathrm{O})$ mode, whereas those observed at 850 and 798 $\mathrm{cm}^{-1}$ are assigned to bridging $\nu_{\text {as }}(\mathrm{W}-\mathrm{O}-\mathrm{W})$ modes. $^{33,34}$ Analysis of the IR spectrum of $\mathrm{Mo}_{3} \mathrm{~S}_{4}-\mathrm{POM}$ appears rather consistent with a saturated metal-oxo framework with regard to the wavenumber range of the $\nu_{\text {as }}(\mathrm{W}-\mathrm{O}-\mathrm{W})$ modes. Vacant POMs give rise to IR vibrations below $800 \mathrm{~cm}^{-1}$. Such a result is consistent with the acidic conditions applied for the synthesis procedure $(\mathrm{pH}=2.3)$ which preclude formation of any lacunary species. At last, the $\mathrm{Mo}_{3} \mathrm{~S}_{4}-\mathrm{POM}$ compound has been characterized by ${ }^{183} \mathrm{~W}$ NMR spectroscopy. The ${ }^{183} \mathrm{~W}$ NMR spectrum (Figure S1) shows a complex pattern consisting of more than $20{ }^{183} \mathrm{~W}$ resonances in the $-100 /-$ $200 \mathrm{ppm}$ chemical shift range differing in their linewidth and relative intensity. ${ }^{35}$ This result evidences that the $\mathrm{Mo}_{3} \mathrm{~S}_{4}-$ POM solid contains a mixture of molecular species which could be isomers or which could differ slightly by their W/ $\mathrm{Mo}_{3} \mathrm{~S}_{4}$ ratio. Nevertheless, the observed resonances exhibit chemical shifts fully consistent with $\mathrm{W}^{\mathrm{VI}}$ centers in octahedral oxo environments. The cationic exchange process from alkali to tetra- $n$-hexylammonium salts alters neither the POM composition nor the IR spectrum (Figure S1).

2.2. Optimization of the Catalyst-Modified Photocathodes for Sunlight-Driven HER. Before investigating the photoelectrocatalytic properties of the best-of-class photocathodes, a preliminary electrochemical study has been carried out to determine the optimal cluster loading leading to maximum catalytic activity. Toward this goal, three cluster loadings [namely, $7.2 \times 10^{-6}, 3.6 \times 10^{-5}$, and $7.2 \times 10^{-5} \mathrm{mmol}$ $\mathrm{cm}^{-2}$ of $\mathrm{Mo}_{3} \mathrm{~S}_{4}(\mathrm{acac}-\mathrm{Bu})$ or $\left.\mathrm{Mo}_{3} \mathrm{~S}_{4}\left(\mathrm{AsW}_{12}\right)\right]$ have been tested for the deposition by drop-casting of the catalyst films onto $\mathrm{Si}(100)-\mathrm{H}$. The photoelectrochemical response of the freshly modified surfaces was then examined as a function of the nature and the amount of the deposited catalyst. As expected, no appreciable reduction current was measured in the dark for all electrodes. As shown in Figure S2, the first cyclic voltammetry scans of $\mathrm{Mo}_{3} \mathrm{~S}_{4}(\mathrm{acac}-\mathrm{Bu})$ - and $\mathrm{Mo}_{3} \mathrm{~S}_{4}\left(\mathrm{AsW}_{12}\right)$ modified $\mathrm{Si}(100)$ photocathodes in $1.0 \mathrm{M} \mathrm{H}_{2} \mathrm{SO}_{4}(\mathrm{pH} 0.3)$ and under simulated sunlight (AM 1.5G, $100 \mathrm{~mW} \mathrm{~cm}^{-2}$ ) revealed a broad and irreversible cathodic prepeak within the range $-0.3 /-0.1 \mathrm{~V}$ versus reversible hydrogen electrode (RHE), followed by the higher HER photocurrent. It must 

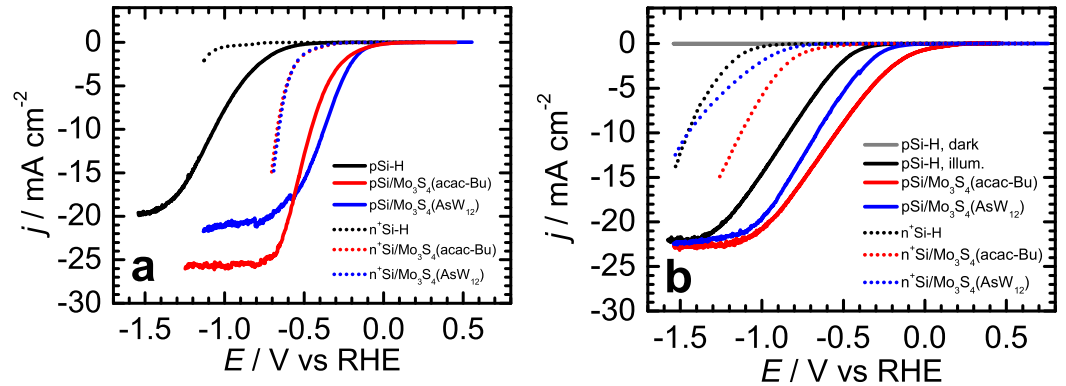

Figure 2. Photoelectrochemical HER at pH 0.3 (a) and 7.3 (b). $i R$-uncorrected LSV curves at $20 \mathrm{mV} \mathrm{s}^{-1}$ of optimized catalyst-modified p-type $\mathrm{Si}(100)$ photocathodes under simulated sunlight (AM 1.5G, $100 \mathrm{~mW} \mathrm{~cm}^{-2}$ ) in $1.0 \mathrm{~mol} \mathrm{~L}^{-1} \mathrm{H}_{2} \mathrm{SO}_{4}$ (a) and $0.1 \mathrm{~mol} \mathrm{~L}^{-1} \mathrm{KCl}+0.5 \mathrm{~mol} \mathrm{~L}^{-1} \mathrm{KHCO}_{3}$ (b). For comparison, LSV curves of modified $\mathrm{n}^{+}$-type $\mathrm{Si}(100)$ surfaces in the dark are also shown. The initial cluster loading was $7.2 \times 10^{-5} \mathrm{mmol}$ $\mathrm{cm}^{-2}$ for $\mathrm{Mo}_{3} \mathrm{~S}_{4}(\mathrm{acac}-\mathrm{Bu})$ and $7.2 \times 10^{-6} \mathrm{mmol} \mathrm{cm}^{-2}$ for $\mathrm{Mo}_{3} \mathrm{~S}_{4}\left(\mathrm{AsW}_{12}\right)$.

Table 1. Performances of the Bare and Catalyst-Modified Si(100) Electrodes for Simulated Sunlight-Assisted HER at pH 0.3 and $7.3^{a}$

\begin{tabular}{|c|c|c|c|c|}
\hline cathode & onset potential $/ \mathrm{V}_{\mathrm{RHE}}^{b}$ & $E\left(E_{\text {corr }}\right) / \mathrm{V}_{\mathrm{RHE}}$ at $-10 \mathrm{~mA} \mathrm{~cm}{ }^{-2 c}$ & $\Delta E_{\mathrm{ons}} / \mathrm{V}^{d}$ & $j_{\mathrm{L}} / \mathrm{mA} \mathrm{cm}^{-2 e}$ \\
\hline \multicolumn{5}{|c|}{ pH 0.3} \\
\hline$p \mathrm{Si}-\mathrm{H}$ & -0.52 & $-1.07(-0.92)$ & 0.37 & -19.9 \\
\hline$p \mathrm{Si} / \mathrm{Mo}_{3} \mathrm{~S}_{4}(\mathrm{acac}-\mathrm{Bu})$ & -0.04 & $-0.45(-0.36)$ & 0.27 & -25.8 \\
\hline$p \mathrm{Si} / \mathrm{Mo}_{3} \mathrm{~S}_{4}\left(\mathrm{AsW}_{12}\right)$ & -0.02 & $-0.37(-0.18)$ & 0.30 & -21.5 \\
\hline$n^{+} \mathrm{Si}-\mathrm{H}^{f}$ & -0.89 & $<-1.30$ & & \\
\hline$n^{+} \mathrm{Si} / \mathrm{Mo}_{3} \mathrm{~S}_{4}(\mathrm{acac}-\mathrm{Bu})^{f}$ & -0.31 & $-0.65(-0.64)$ & & \\
\hline$n^{+} \mathrm{Si} / \mathrm{Mo}_{3} \mathrm{~S}_{4}\left(\mathrm{AsW}_{12}\right)^{f}$ & -0.32 & $-0.68(-0.63)$ & & \\
\hline \multicolumn{5}{|c|}{ pH 7.3} \\
\hline$p \mathrm{Si}-\mathrm{H}$ & -0.32 & $-0.84(-0.57)$ & $0.66(0.45)$ & -22.0 \\
\hline$p \mathrm{Si} / \mathrm{Mo}_{3} \mathrm{~S}_{4}(\mathrm{acac}-\mathrm{Bu})$ & +0.11 & $-0.54(-0.22)$ & $0.71(0.30)$ & -22.7 \\
\hline$p \mathrm{Si} / \mathrm{Mo}_{3} \mathrm{~S}_{4}\left(\mathrm{AsW}_{12}\right)$ & -0.18 & $-0.66(-0.44)$ & $0.64(0.22)$ & -22.3 \\
\hline$n^{+} \mathrm{Si}-\mathrm{H}^{f}$ & -0.98 & $-1.46(-1.31)$ & & \\
\hline $\mathrm{n}^{+} \mathrm{Si} / \mathrm{Mo}_{3} \mathrm{~S}_{4}(\mathrm{acac}-\mathrm{Bu})^{f}$ & -0.60 & $-1.25(-0.94)$ & & \\
\hline $\mathrm{n}^{+} \mathrm{Si} / \mathrm{Mo}_{3} \mathrm{~S}_{4}\left(\mathrm{AsW}_{12}\right)^{f}$ & -0.82 & $-1.45(-1.28)$ & & \\
\hline
\end{tabular}

${ }^{a}$ Determined from stable photocurrent-potential curves. ${ }^{b}$ Determined for a current density of $0.25 \mathrm{~mA} \mathrm{~cm}{ }^{-2}$. ${ }^{c}$ Between parentheses, $i R$-corrected potential values. ${ }^{d}$ Difference between onset potentials of illuminated p-type and dark $\mathrm{n}^{+}$-type electrodes. Between parentheses ( $\mathrm{pH} 7.3$ ), values obtained when dark $\mathrm{n}^{+}$-type electrodes were replaced by glassy carbon ones. ${ }^{e}$ Plateau current density corresponding to the light-limited catalytic current. ${ }^{f}$ In the dark.

be pointed out that this cathodic prepeak was absent in the following scans and stable sigmoidal photocurrent curves showing the catalytic HER wave were usually obtained after two scans for all tested catalysts and concentrations (Figure 2). The disappearance of such a cathodic prepeak has been previously observed by Jaramillo et al. ${ }^{36}$ and Tran et al. ${ }^{37}$ for $\left[\mathrm{Mo}_{3} \mathrm{~S}_{4}\right]^{4+}$ and $\left[\mathrm{Mo}_{3} \mathrm{~S}_{13}\right]^{2-}$ cluster-modified surfaces, respectively. It is consistent with either the irreversible conversion of the deposited film into a new material, which is the active form of the catalyst or the cathodic desorption of the cluster into the electrolytic solution, as also proposed by Kristensen et al. ${ }^{38}$ In this work, atomic force microscopy (AFM) and X-ray photoelectron spectroscopy (XPS) measurements provide strong experimental evidence that these two events occurred concomitantly upon the electrochemical reduction of the modified photocathodes (vide infra). In the first event, we can thus hypothesize that the reduction of $\mathrm{Mo}$ (IV) to $\mathrm{Mo}$ (III) is accompanied by the replacement of $\mathrm{S}^{2-}$ sulfido ligands in the cluster by oxo $\mathrm{O}^{2-}$ groups, leading to the formation of a mixed $\mathrm{O} / \mathrm{S}$ mixed valence core $\left\{\mathrm{Mo}(\mathrm{IV})_{3-x} \mathrm{Mo}(\mathrm{III})_{x} \mathrm{O}_{4-n} \mathrm{~S}_{n}\right\}^{(4-x)+}$, as evidenced by post-electrochemistry XPS analysis (vide infra) and electrochemical measurements of the complexes in solution at a conventional glassy carbon electrode (Figure S4). For the latter, the observed $\mathrm{Mo}(\mathrm{IV}) / \mathrm{Mo}$ (III) reduction potential was very close to that previously reported for analogous $\left[\mathrm{Mo}_{3} \mathrm{~S}_{4}\right]^{4+}$-based clusters. ${ }^{39}$ At $\mathrm{pH} 7.3$, this cathodic prepeak was either much less intense for the $\mathrm{Mo}_{3} \mathrm{~S}_{4}(\mathrm{acac}-\mathrm{Bu})$ modified electrode or no longer observed for the immobilized catalyst $\mathrm{Mo}_{3} \mathrm{~S}_{4}\left(\mathrm{AsW}_{12}\right)$ (Figure S3).

Considering the stabilized catalytic response of the photocathodes, it can be emphasized that surfaces prepared from $\mathrm{Mo}_{3} \mathrm{~S}_{4}(\mathrm{acac}-\mathrm{Bu})$ and $\mathrm{Mo}_{3} \mathrm{~S}_{4}\left(\mathrm{AsW}_{12}\right)$ loadings of $7.2 \times 10^{-5}$ and $7.2 \times 10^{-6} \mathrm{mmol} \mathrm{cm}^{-2}$, respectively, provided the highest photocurrent densities combined to lowest onset potentials

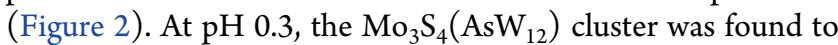
be catalytically superior to $\mathrm{Mo}_{3} \mathrm{~S}_{4}(\mathrm{acac}-\mathrm{Bu})$ at low overpotentials (above $-0.5 \mathrm{~V}$ vs $\mathrm{RHE}$ ) as the resulting photocathode showed a higher onset potential $(-0.02 \mathrm{~V}$ vs $\mathrm{RHE}$ against $-0.04 \mathrm{~V})$ and a lower overvoltage at $10 \mathrm{~mA} \mathrm{~cm}{ }^{-2}(0.37$ $\mathrm{V}$ against $0.45 \mathrm{~V}$, corresponding to $0.18 \mathrm{~V}$ against $0.36 \mathrm{~V}$ when the cell resistance was compensated) (Figure S5). For potentials more negative than $-0.5 \mathrm{~V}$ versus RHE, the $\mathrm{Mo}_{3} \mathrm{~S}_{4}$ (acac-Bu)-modified photocathode yielded higher photocurrent densities probably owing to a higher amount of the deposited catalyst. Compared with $\mathrm{Si}(100)-\mathrm{H}$ illuminated under similar conditions, the decrease in the overpotential for HER measured at $10 \mathrm{~mA} \mathrm{~cm}$ was approximately 700-740 and 560-620 mV (whether Ohmic drop was corrected or not) for the $\mathrm{Mo}_{3} \mathrm{~S}_{4}\left(\mathrm{AsW}_{12}\right)$ - and $\mathrm{Mo}_{3} \mathrm{~S}_{4}(\mathrm{acac}-\mathrm{Bu})$-modified photocathodes, respectively. 

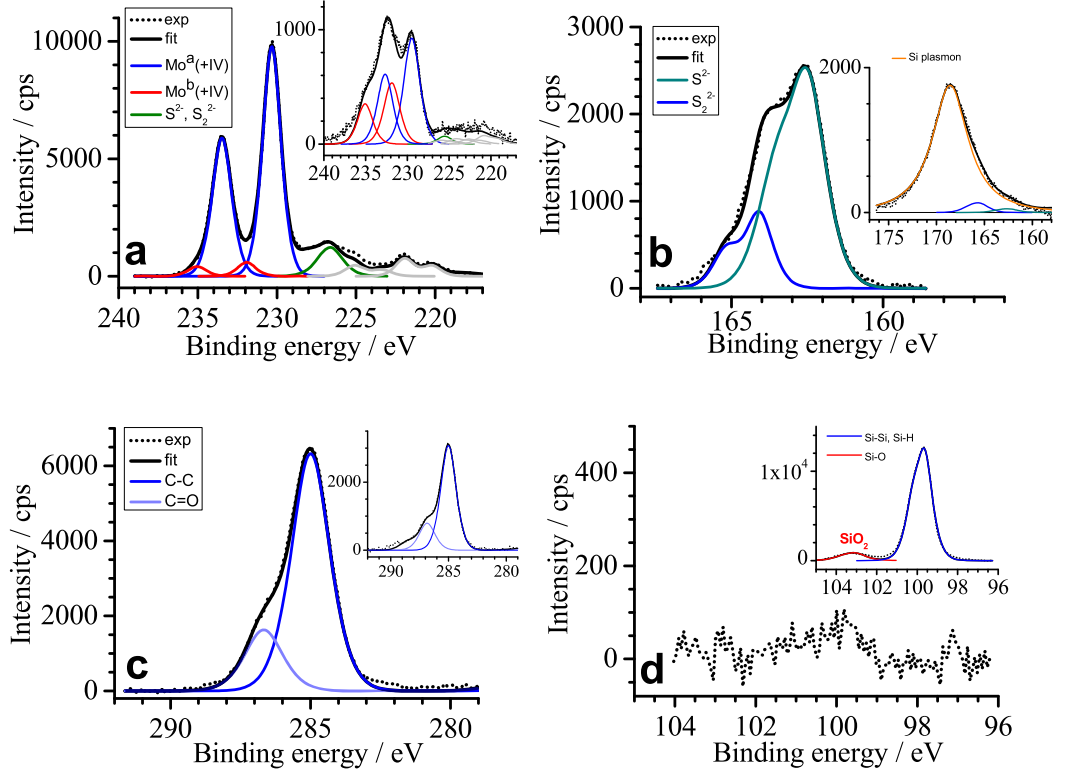

Figure 3. Mo $3 \mathrm{~d}$ and S 2s (a), S 2p (b), C 1s (c), and Si 2p (d) high-resolution XPS spectra of the freshly prepared $\mathrm{Mo}_{3} \mathrm{~S}_{4}(\mathrm{acac}-\mathrm{Bu})$-modified surface before and after cathodic electrolysis at $-0.84 \mathrm{~V}$ vs RHE for $2 \mathrm{~h}$ under simulated sunlight (insets). The peaks observed below $225 \mathrm{eV}$ (highlighted in gray) are attributed to satellite peaks of the used XPS source. Experimental data and fitting envelopes are represented by black dotted and continuous lines, respectively. The colored lines are fitted curves using Gaussian-Lorentzian mixed peaks corresponding to different components. The initial cluster loading was $7.2 \times 10^{-5} \mathrm{mmol} \mathrm{cm}^{-2}$.

Focusing on the potential necessary to reach a current density of $10 \mathrm{~mA} \mathrm{~cm}{ }^{-2}$ as an electrode activity metric, the $i R$ corrected value determined for the photocathode modified with $\mathrm{Mo}_{3} \mathrm{~S}_{4}\left(\mathrm{AsW}_{12}\right)$ is well in line with $180-200 \mathrm{mV}$ values reported for highly active $\left(\mathrm{Mo}_{3} \mathrm{~S}_{13}\right)^{2-} \cdot{ }^{40-42} \mathrm{MoS}_{2}$ nanomaterials deposited on planar substrates (e.g., fluorine-doped tin oxide and glassy carbon) exhibited a lower activity for HER as these catalysts achieved $10 \mathrm{~mA} \mathrm{~cm}{ }^{-2}$ at $\sim 200-250 \mathrm{mV}$ overpotentials. $^{40}$ Not surprisingly, $\mathrm{MoS}_{2}$ deposited on high surface area electrodes (graphene oxide, carbon fiber paper, and carbon nanotubes) demonstrated excellent activity characterized by only $110-150 \mathrm{mV}$ overpotential. ${ }^{40,43-46}$

Moreover, from the difference between the onset potentials of the nonphotoactive-modified $\mathrm{n}^{+}$-type Si (Figures 2 and S6) and illuminated p-type Si electrodes, it can be deduced that the semiconductor produces a photovoltage of $0.30 \mathrm{~V}$ when the deposited catalyst is $\mathrm{Mo}_{3} \mathrm{~S}_{4}\left(\mathrm{AsW}_{12}\right)$ and $0.27 \mathrm{~V}$ when the catalyst is $\mathrm{Mo}_{3} \mathrm{~S}_{4}(\mathrm{acac}-\mathrm{Bu})$. Both values are however smaller than that determined for $\mathrm{Si}(100)-\mathrm{H}$ (i.e., $0.37 \mathrm{~V}$ ), as a result of enhanced recombination of photogenerated charge carriers.

At $\mathrm{pH} 7.3$, the catalytic performance of the $\mathrm{Mo}_{3} \mathrm{~S}_{4}\left(\mathrm{AsW}_{12}\right)$ modified photocathode was found to be lower than that of the $\mathrm{Mo}_{3} \mathrm{~S}_{4}$ (acac-Bu)-modified photocathode irrespective of the examined potential range, as supported by a lower onset potential $(-0.18 \mathrm{~V}$ against $+0.11 \mathrm{~V})$ and a higher overpotential at $10 \mathrm{~mA} \mathrm{~cm}{ }^{-2}(0.66 \mathrm{~V}$ against $0.54 \mathrm{~V}$, corresponding to 0.44 $\mathrm{V}$ against $0.22 \mathrm{~V}$ when the cell resistance was compensated) (Table 1). Moreover, the difference between the onset potentials of the nonphotoactive-modified $n^{+}$-type $\mathrm{Si}$ and illuminated p-type Si electrodes yielded clearly abnormally high photovoltage values, exceeding $0.60 \mathrm{~V}$ for both types of photocathodes. More reasonable values ranging from 0.22 to $0.45 \mathrm{~V}$ were determined when $\mathrm{n}^{+}$-type $\mathrm{Si}$ electrodes were replaced by more conventional glassy carbon ones (Figure S7). Such results could be partly explained by differences in the catalyst-support interactions and/or surface energetics ${ }^{47}$ of $\mathrm{n}^{+}$- and $\mathrm{p}$-doped silicon at neutral $\mathrm{pH}$.

2.3. Electrochemistry-Induced Structural Changes. The chemical composition and the morphology of the asdeposited and electrochemically reduced cluster films were examined by means of XPS and AFM. First, XPS measurements have been performed on the two types of optimized photocathodes to gain insights about the composition and molecular structure of the as-deposited films and about the nature of the catalytically active species. With the main carbon C 1s peak set at $285.0 \mathrm{eV}$, the characteristic peaks related to the cluster core are observed.

The freshly prepared $\mathrm{Mo}_{3} \mathrm{~S}_{4}($ acac-Bu$)$-modified surface shows the main Mo $3 \mathrm{~d}_{5 / 2}$ and Mo $3 \mathrm{~d}_{3 / 2}$ lines at 230.3 and $233.4 \mathrm{eV}$, respectively, which are consistent with molybdenum in the formal +4 state (Figures 3 and S8).$^{48}$ Additionally, two minor components of Mo $3 \mathrm{~d}$ are observed at 231.9 and 235.1 $\mathrm{eV}$, which can be ascribed to $\mathrm{Mo}(\mathrm{IV}+)$ atoms in a different local environment, as previously reported by Jaramillo et al. ${ }^{36}$ The presence of sulfur is evidenced by the $S 2$ s signal at 226.6 $\mathrm{eV}$. The $\mathrm{S} 2 \mathrm{p}$ region shows a main peak at $162.6 \mathrm{eV}$ corresponding to unresolved contributions of $2 p_{1 / 2}$ and $2 p_{3 / 2}$ doublet of $\mathrm{S}^{2-}$ ligands. A second minor peak at $164.1 \mathrm{eV}$ is also observed, which suggests the concomitant presence of $\mathrm{S}_{2}{ }^{2-}$ groups. Such observations are in perfect line with previous reports of molybdenum sulfide materials, which incorporate sulfur atoms in different oxidation states. ${ }^{49,50}$ The experimental ratio between the areas under the Mo and $S$ peaks is estimated at 0.75 , as theoretically expected. Moreover, the $\mathrm{C} 1 \mathrm{~s}$ spectrum shows a main component at $285.0 \mathrm{eV}$ and a shoulder at 286.8 $\mathrm{eV}$, which are attributed to $\mathrm{C}-\mathrm{C}$ and $\mathrm{C}=\mathrm{O}$ bonds of the (acac-Bu) ligand, respectively. The corresponding $\mathrm{C}-\mathrm{C} / \mathrm{C}-\mathrm{O}$ peak area ratio of 3.8 was also fully consistent with the expected atomic composition of the acac-Bu ligand (i.e. 7/2).

Now, for the freshly prepared $\mathrm{Mo}_{3} \mathrm{~S}_{4}\left(\mathrm{AsW}_{12}\right)$-modified surface, the two Mo $3 \mathrm{~d}_{5 / 2}$ peaks attributed to locally different 

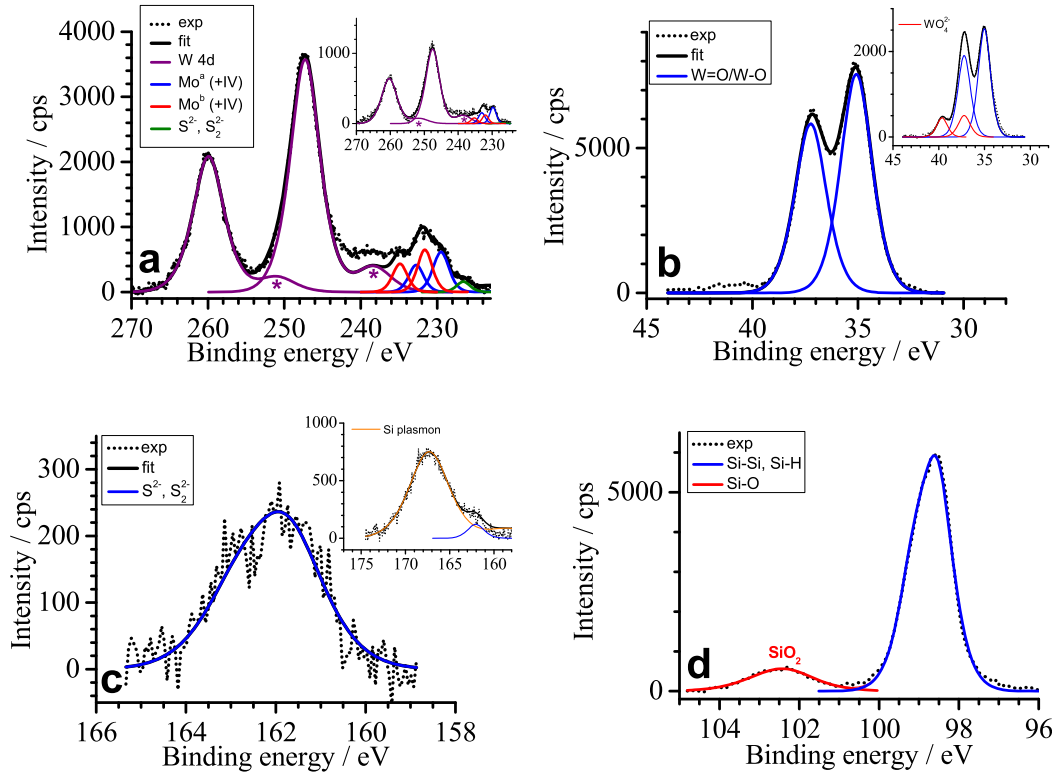

Figure 4. W 4d, Mo 3d, and S 2s (a), W 4f (b), and S 2p (c) high-resolution XPS spectra of the freshly prepared $\mathrm{Mo}_{3} \mathrm{~S}_{4}\left(\mathrm{AsW}_{12}\right)$-modified surface before and after cathodic electrolysis at $-0.84 \mathrm{~V}$ vs RHE for $2 \mathrm{~h}$ under simulated sunlight (insets). Post-electrolysis Si $2 \mathrm{p}$ spectrum (d). The peaks observed at 238.3 and $251.1 \mathrm{eV}$ (indicated by asterisks) are attributed to satellite peaks of the used XPS source. Experimental data and fitting envelopes are represented by black dotted and continuous lines, respectively. The colored lines are fitted curves using Gaussian-Lorentzian mixed peaks corresponding to different components. The initial cluster loading was $7.2 \times 10^{-6} \mathrm{mmol} \mathrm{cm}^{-2}$.

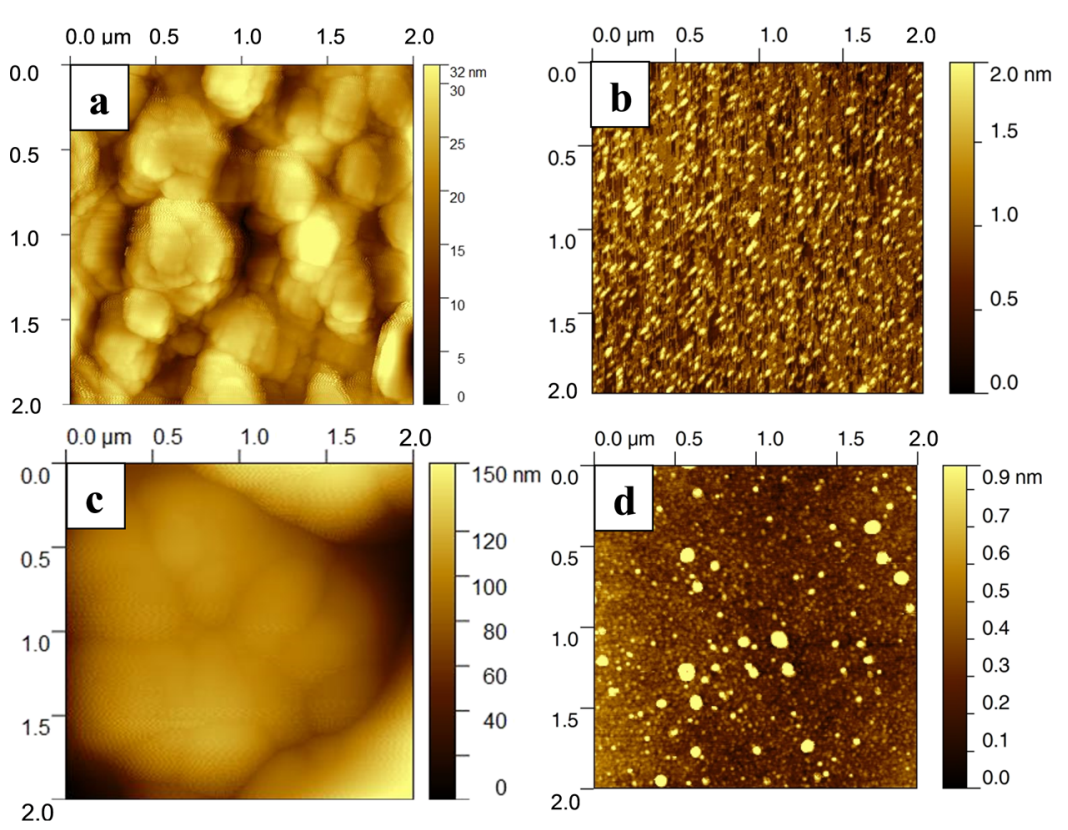

Figure 5. AFM images of $\mathrm{Mo}_{3} \mathrm{~S}_{4}(\mathrm{acac}-\mathrm{Bu})-(\mathrm{a}, \mathrm{b})$ and $\mathrm{Mo}_{3} \mathrm{~S}_{4}\left(\mathrm{AsW}_{12}\right)-(\mathrm{c}, \mathrm{d})$ modified $\mathrm{Si}(100)$ surfaces before $(\mathrm{a}, \mathrm{c})$ and after cathodic electrolysis at $-0.84 \mathrm{~V}$ vs RHE for $2 \mathrm{~h}$ under simulated sunlight $(\mathrm{b}, \mathrm{d})$. The initial cluster loading of optimized surfaces was $7.2 \times 10^{-5} \mathrm{mmol} \mathrm{cm} \mathrm{cor}^{-2}$ for $\mathrm{Mo}_{3} \mathrm{~S}_{4}(\mathrm{acac}-\mathrm{Bu})$ and $7.2 \times 10^{-6} \mathrm{mmol} \mathrm{cm}^{-2}$ for $\mathrm{Mo}_{3} \mathrm{~S}_{4}\left(\mathrm{AsW}_{12}\right)$. Scan size: $2 \times 2 \mu \mathrm{m}^{2}$.

$\mathrm{Mo}(4+)$ atoms are observed at 229.5 and $231.6 \mathrm{eV}$ (Figures 4 and S9). Furthermore, the presence of $\mathrm{S}^{2-}$ and $\mathrm{S}_{2}{ }^{2-}$ groups is also evidenced by the $S 2$ s and S 2 p signals at 226.6 and 161.9 $\mathrm{eV}$, respectively. The ratio between the peak areas of the total Mo and S signals is 0.74 , as theoretically expected. The $\mathrm{W} 4 \mathrm{f}$ and $\mathrm{W} 4 \mathrm{~d}$ lines observed at $35.1\left(\mathrm{~W} 4 \mathrm{f}_{7 / 2}\right), 37.2\left(\mathrm{~W}_{4 / 2}\right)$, $247.3\left(\mathrm{~W} 4 \mathrm{~d}_{5 / 2}\right)$, and $259.9\left(\mathrm{~W} 4 \mathrm{~d}_{3 / 2}\right) \mathrm{eV}$ are consistent with $\mathrm{W}-\mathrm{O} / \mathrm{W}=\mathrm{O}$ species involving tungsten in the formal +6 state. $^{51-53}$ The experimental ratio Mo $3 \mathrm{~d}_{5 / 2} / \mathrm{W} \quad 4 \mathrm{~d}_{3 / 2}$ is estimated at 0.23 , in close agreement with the theoretical ratio (i.e., 0.25 ).
After cathodic electrolysis for $2 \mathrm{~h}$ with the deposited clusters, both the intensity and the position of the characteristic XPS signals were strongly modified. For both photocathodes, a large amount of the deposited material has been released into the electrolyte solution during the electrochemical test (about 90 and $70 \%$ for $\mathrm{Mo}_{3} \mathrm{~S}_{4}(\mathrm{acac}-\mathrm{Bu})$ - and $\mathrm{Mo}_{3} \mathrm{~S}_{4}\left(\mathrm{AsW}_{12}\right)$-modified surfaces, respectively), as confirmed by the dramatic decrease in the intensity of Mo 3d, W 4d, W 4f, and S 2p XPS signals concomitantly with the appearance of both the Si plasmon loss peak and Si $2 \mathrm{p}$ signal (insets in Figures 3 and 4). Such observations are in line with those reported for other $\left\{\mathrm{Mo}_{3} \mathrm{~S}_{4}\right\}$ - 

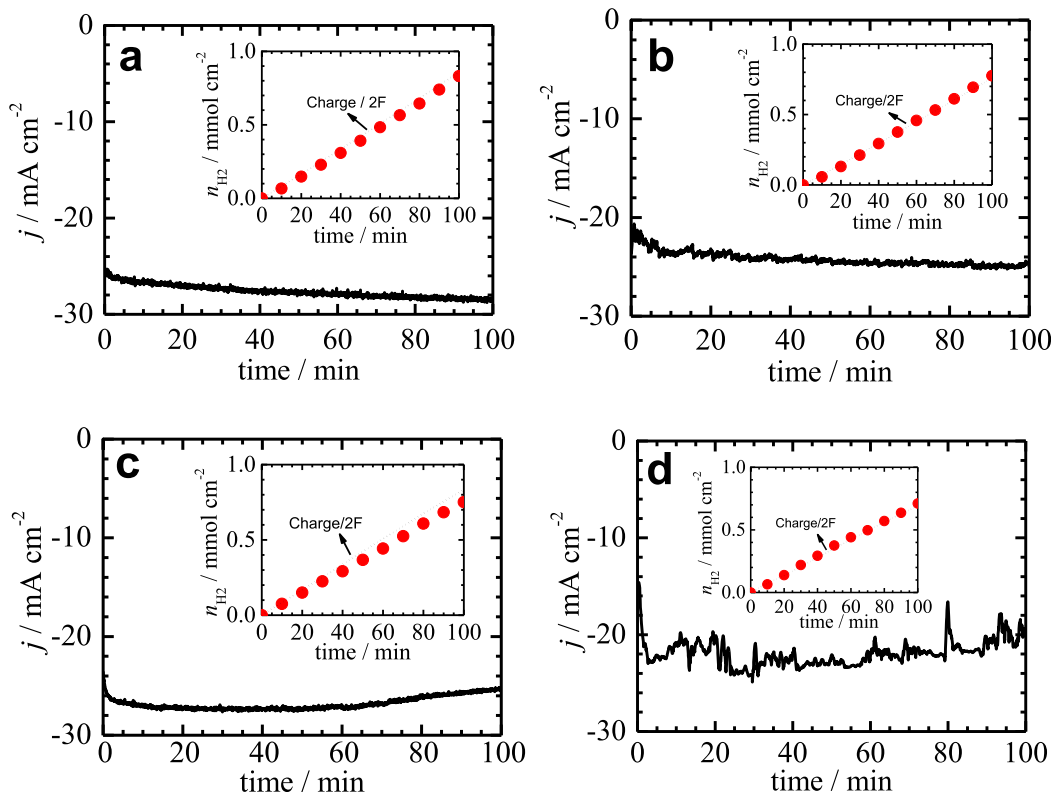

Figure 6. Photocurrent density-time curves under continuous illumination obtained during the controlled potential electrolysis at $-0.84 \mathrm{~V}$ vs RHE in a $\mathrm{pH} 0.3$ solution $(\mathrm{a}, \mathrm{b})$ or $-1.04 \mathrm{~V}$ vs $\mathrm{RHE}$ in a $\mathrm{pH} 7.3$ solution $(\mathrm{c}, \mathrm{d})$ using optimized $\mathrm{Mo}_{3} \mathrm{~S}_{4}(\mathrm{acac}-\mathrm{Bu})(\mathrm{a}, \mathrm{c})$ or $\mathrm{Mo}_{3} \mathrm{~S}_{4}\left(\mathrm{AsW}_{12}\right)(\mathrm{b}, \mathrm{d})$-modified photocathodes. (Insets) Amount of $\mathrm{H}_{2}$ evolved at the photocathode as a function of the electrolysis time. The mole number of produced gas was calculated from the gas volume trapped in a Hoffman cell. The dotted black lines correspond to the theoretical fit assuming a 100\% Faradaic efficiency. The current fluctuations are caused by the removal of $\mathrm{H}_{2}$ bubbles from the photocathode surface. The surface areas of the photoelectrodes are $0.30(\mathrm{a}), 0.50(\mathrm{~b}), 0.49(\mathrm{c})$, and $0.51(\mathrm{~d}) \mathrm{cm}^{2}$.

based cluster-modified surfaces. ${ }^{13,38}$ As a matter of fact, the $\mathrm{H}_{2}$ bubbling at the surface of the photocathode provokes mechanical desorption of a large upper part of the immobilized layer which does not participate in the catalytic process. Moreover, the main Mo $3 \mathrm{~d}_{5 / 2}$ and Mo $3 \mathrm{~d}_{3 / 2}$ lines of the electrochemically reduced $\mathrm{Mo}_{3} \mathrm{~S}_{4}(\mathrm{acac}-\mathrm{Bu})$-modified surface were shifted to 229.4 and $232.6 \mathrm{eV}$, respectively, which would be consistent with partial substitution of $\mathrm{S}^{2-}$ sulfido ligands by $\mathrm{O}^{2-}$ oxo groups in the metallic cluster. Such an assumption is supported by the XPS spectra of $\left[\mathrm{Mo}_{3} \mathrm{O}_{4-n} \mathrm{~S}_{n}\right]^{4+54}$ or refers to the presence of $\mathrm{Mo}(\mathrm{III}+)$ in the cluster structure. ${ }^{55}$ The Mo $3 \mathrm{~d}$ component having the highest energy (assigned to $\mathrm{Mo}(\mathrm{IV}+$ ) atoms in a different local environment) was not affected by the electrolytic treatment, both in intensity and position. This leads to the hypothesis that this component could be the signature of the surface-confined, stable, and catalytically active clusters. For the cathodically reduced $\mathrm{Mo}_{3} \mathrm{~S}_{4}\left(\mathrm{AsW}_{12}\right)$-modified surface, the Mo $3 \mathrm{~d}$ lines of the two components were only 0.3 $\mathrm{eV}$ shifted toward more positive binding energies. Such a result would be rather consistent with a weaker lability of $S^{2-}$ ligands in the cluster incorporating the POM. Additionally, the W $4 \mathrm{f}$ spectrum shows an additional component at higher binding energies (37.2 and $39.6 \mathrm{eV}$ for the $4 \mathrm{f}_{7 / 2}$ and $4 \mathrm{f}_{5 / 2}$ levels, respectively) that can be assigned to the formation of some tungstate species. ${ }^{56}$ Finally, the $\mathrm{Si} 2 \mathrm{p}$ spectrum shows the presence of a substantial amount of silicon oxides at about 102-103 eV for both cathodically reduced photocathodes. However, it could not be ruled out that the oxidation of the silicon surface was either caused by the cathodic electrolysis or already present after the catalyst deposition because the Si $2 p$ signal for the freshly prepared photocathodes was totally attenuated because of the thick catalyst layer.

From XPS data and using the treatment reported by Cicero et al., ${ }^{57}$ if one considers the $\mathrm{Si}(100)$ surface atom density of 6.8 $\times 10^{14}$ atoms cm $\mathrm{cm}^{-2}, 58$ the surface coverages of the catalyst remaining after cathodic electrolysis can be estimated at $(8.0 \pm$ $0.5) \times 10^{13}$ and $(2.0 \pm 0.6) \times 10^{13} \mathrm{~cm}^{-2}$ for the $\mathrm{Mo}_{3} \mathrm{~S}_{4}($ acac$\mathrm{Bu})$ - and $\mathrm{Mo}_{3} \mathrm{~S}_{4}\left(\mathrm{AsW}_{12}\right)$-modified photocathodes, respectively (see the Supporting Information).

Electrochemistry-induced changes derived from XPS were also corroborated by the AFM analysis of the optimized photocathodes. After the catalyst deposition, both surfaces showed a rough and compact granular structure characterized by the presence of a few hundreds of nanometer large agglomerates (Figure 5). The root-mean-square ( $\mathrm{rms}$ ) roughness was measured at ca. $6.0 \pm 0.5$ and $26.0 \pm 2 \mathrm{~nm}$ for the $\mathrm{Mo}_{3} \mathrm{~S}_{4}(\mathrm{acac}-\mathrm{Bu})$ - and $\mathrm{Mo}_{3} \mathrm{~S}_{4}\left(\mathrm{AsW}_{12}\right)$-modified surfaces, respectively. After cathodic electrolysis, a much less dense array was observed with the presence of a few tens of nanometer large catalyst aggregates and the surface of underlying silicon became now visible. The rms roughness values were therefore considerably decreased and lower than $1.0 \mathrm{~nm}$ for both surfaces. The processing of AFM images yielded cluster surface density values of $(4.7 \pm 0.8) \times 10^{13}$ and $(6.4 \pm 0.8) \times 10^{12}$ $\mathrm{cm}^{-2}$ for the $\mathrm{Mo}_{3} \mathrm{~S}_{4}(\mathrm{acac}-\mathrm{Bu})$ - and $\mathrm{Mo}_{3} \mathrm{~S}_{4}\left(\mathrm{AsW}_{12}\right)$-modified surfaces, respectively, considering the theoretical projected specific area of one cluster (Figures S10 and S11). Different reasons can be involved to explain such discrepancies between the cluster densities extracted from XPS and AFM data, especially for the $\mathrm{Mo}_{3} \mathrm{~S}_{4}\left(\mathrm{AsW}_{12}\right)$-modified surface. AFM is believed to be a less reliable technique than XPS to estimate such a parameter essentially due to large uncertainties arising from (i) the calculation method based on the microscale analysis of the surface, (ii) the used processing method that is based on the detection of a size threshold to determine the surface area covered by the cluster, and (iii) the differences between the experimental and theoretical specific areas occupied by the cluster.

2.4. Faradaic Efficiency and Turnover Frequency of the Photocathodes for Solar-Driven HER. The cluster- 

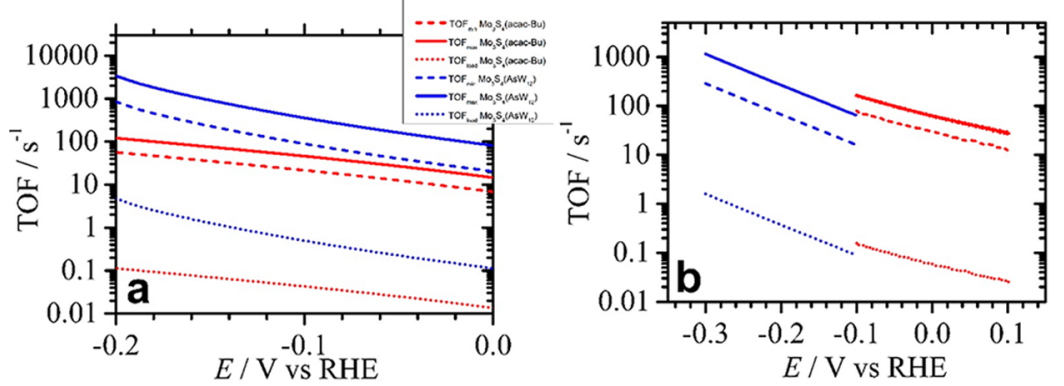

Figure 7. TOF of the $\mathrm{Mo}_{3} \mathrm{~S}_{4}(\mathrm{acac}-\mathrm{Bu})$ (red lines) and $\mathrm{Mo}_{3} \mathrm{~S}_{4}\left(\mathrm{AsW}_{12}\right)$ (blue lines) clusters deposited on p-type $\mathrm{Si}(100)$ surfaces for simulated sunlight-driven HER at pH 0.3 (a) and 7.3 (b). The minimum $\left(\mathrm{TOF}_{\min }\right.$, dashed lines) and maximum (TOF $\mathrm{max}_{\text {malid }}$ solines) TOF numbers were determined from upper and lower limits of the post-electrolysis cluster densities, respectively, estimated from XPS and AFM data. TOF load $($ dotted lines) was calculated from the initial loading of the deposited cluster.

supported photoelectrodes exhibiting the best electrocatalytic efficiencies [namely, those prepared from a cluster loading of $7.2 \times 10^{-5} \mathrm{mmol} \mathrm{cm}^{-2}$ for $\mathrm{Mo}_{3} \mathrm{~S}_{4}(\mathrm{acac}-\mathrm{Bu})$ or $7.2 \times 10^{-6}$ mmol cm ${ }^{-2}$ for $\left.\mathrm{Mo}_{3} \mathrm{~S}_{4}\left(\mathrm{AsW}_{12}\right)\right]$ were tested for more than $1 \mathrm{~h}$ in both electrolytic media under simulated sunlight. As shown in Figure 6, the photocurrent densities measured during the controlled potential electrolysis tests were in quite good agreement with those derived from linear sweep voltammetry (LSV) curves. Moreover, a careful examination of all chronoamperometric curves shows a short initial period (about $5 \mathrm{~min}$ ) for which the cathodic current increases before stabilizing. This beneficial effect results probably from the loss of a large amount of deposited clusters, as supported by the post-electrolysis XPS and AFM data (vide supra), leading to both a better light collection and higher conductivity at the solid-liquid interface.

At $\mathrm{pH}$ 0.3, the photocurrent densities measured for both photoelectrodes remained relatively stable during the electrolysis time (Figure 6). The amount of evolved $\mathrm{H}_{2}$ was determined from the gas volume by measuring the amount of the electrolytic solution displaced in a sealed and graduated upside-down burette (Hoffman cell). ${ }^{59} \mathrm{H}_{2}$ was quantitatively produced (Faradaic efficiency of $98 \pm 2 \%$ ) with a rate of 0.48 $\pm 0.02 \mathrm{mmol} \mathrm{cm}^{-2} \mathrm{~h}^{-1}$, irrespective of the nature of the tested cluster. At $\mathrm{pH} 7.3$, both photocathodes were less stable but the production rate of $\mathrm{H}_{2}$ was almost unchanged. Noticeably, the Faradaic efficiency for the photocathode incorporating $\mathrm{Mo}_{3} \mathrm{~S}_{4}\left(\mathrm{AsW}_{12}\right)$ was higher than that with $\mathrm{Mo}_{3} \mathrm{~S}_{4}(\mathrm{acac}-\mathrm{Bu})$, $99 \pm 1 \%$ against $91 \pm 1 \%$.

To quantify the catalytic efficiency of a system, the turnover frequency (TOF) as a function of the electrode potential has been determined. ${ }^{40,60}$ For a HER catalyst, the TOF corresponds to the ratio of the number of $\mathrm{H}_{2}$ moles produced per second to the number of moles of catalytically active sites (see the Supporting Information for more details). It is therefore essential that the contribution of the electrode surface in the catalytic process is eliminated. Consequently, in this work, this quantity was determined from $i R$-corrected LSV curves of the optimized $\mathrm{Mo}_{3} \mathrm{~S}_{4}($ acac-Bu$)$ - and $\mathrm{Mo}_{3} \mathrm{~S}_{4}\left(\mathrm{AsW}_{12}\right)$ modified photocathodes (Figure S5) within a potential window corresponding to the foot of the catalytic wave, ${ }^{61}$ that is, -0.2 to $0.0 \mathrm{~V}$ versus $\mathrm{RHE}$ (for both clusters at $\mathrm{pH} 0.3$ ), -0.1 to $0.1 \mathrm{~V}$ versus $\mathrm{RHE}$ [for the $\mathrm{Mo}_{3} \mathrm{~S}_{4}(\mathrm{acac}-\mathrm{Bu})$ cluster at $\mathrm{pH}$ 7.3], or -0.3 to $-0.1 \mathrm{~V}$ versus $\mathrm{RHE}$ [for the $\mathrm{Mo}_{3} \mathrm{~S}_{4}\left(\mathrm{AsW}_{12}\right)$ cluster at $\mathrm{pH}$ 7.3]. It is noteworthy that limitations by the mass transport can be considered as negligible owing to the high concentration of the electrolyte.
Moreover, another critical issue is the determination of the exact number of the active sites present at the electrode surface because it is quite obvious that an underestimation of this quantity will yield an overestimation of the TOF. In this work and according to previous reports on thiomolybdate-based HER electrocatalysts, ${ }^{13,36}$ the number of active sites should correspond to the cluster density remaining after the cathodically induced desorption step and estimated from two different methods, namely XPS and AFM. Thereby, this is supported by the stability of both the photocurrents measured at $\mathrm{pH} 0.3$ during preparative-scale electrolysis for a few tens of hours and by the LSV response after electrolysis, as shown in the next section. Nevertheless, for comparison, TOF values calculated using the initial loading of the deposited cluster are

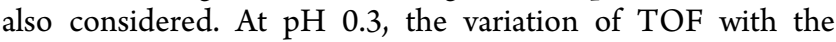
electrode potential confirms the higher catalytic activity of the cluster $\mathrm{Mo}_{3} \mathrm{~S}_{4}\left(\mathrm{AsW}_{12}\right)$ compared to $\mathrm{Mo}_{3} \mathrm{~S}_{4}($ acac-Bu) (Figure 7). From the post-electrochemistry cluster density, TOF values in the range $20-80$ and $6-14 \mathrm{~s}^{-1}$ were estimated at $0 \mathrm{~V}$ versus RHE for the $\mathrm{Mo}_{3} \mathrm{~S}_{4}\left(\mathrm{AsW}_{12}\right)$ and $\mathrm{Mo}_{3} \mathrm{~S}_{4}(\mathrm{acac}-\mathrm{Bu})$ clusters, respectively. Respective values of ca. $850-3300$ and 50-120 $\mathrm{s}^{-1}$ were reached at $-0.2 \mathrm{~V}$ versus RHE. At $\mathrm{pH} 7.3$, the trend was inversed with $\mathrm{Mo}_{3} \mathrm{~S}_{4}(\mathrm{acac}-\mathrm{Bu})$ being more active than $\mathrm{Mo}_{3} \mathrm{~S}_{4}\left(\mathrm{AsW}_{12}\right)$ (Figure $7 \mathrm{~b}$ ). The TOF values fall in the 60$250 \mathrm{~s}^{-1}$ range for $\mathrm{Mo}_{3} \mathrm{~S}_{4}\left(\mathrm{AsW}_{12}\right)$ at an overpotential of $0.2 \mathrm{~V}$, whereas $\mathrm{Mo}_{3} \mathrm{~S}_{4}(\mathrm{acac}-\mathrm{Bu})$ yielded $30-60 \mathrm{~s}^{-1}$ TOF values at $0 \mathrm{~V}$ versus RHE.

Such exceptional values have never been reported for thiomolybdate-based HER electrocatalysts ${ }^{41,62}$ so far and exhibit ca. 2-3 orders of magnitude higher than those reported for the most active molybdenum sulfides, such as $\mathrm{MoS}_{2}$ nanoparticles supported on $\mathrm{Au}(111) .{ }^{41,63}$ Much smaller TOF values [for instance, ca. 6 and $0.1 \mathrm{~s}^{-1}$ for $\mathrm{Mo}_{3} \mathrm{~S}_{4}\left(\mathrm{AsW}_{12}\right)$ and $\mathrm{Mo}_{3} \mathrm{~S}_{4}(\mathrm{acac}-\mathrm{Bu})$, respectively, at $-0.2 \mathrm{~V}$ versus $\mathrm{RHE}$ and $\mathrm{pH} 0.3$ ] competing with that of the best molybdenum sulfidebased HER catalysts ${ }^{41}$ are calculated if the number of active cluster sites is assumed to be equal to the initial loading of the deposited cluster (Figure 7). As a matter of fact, a mean TOF between these two extreme limits should be rather representative of the real catalytic activity of the immobilized cocatalysts. Importantly, a special care must be taken to the comparison of our TOF values estimated at a certain overpotential with those determined for other molybdenum sulfide- or thiomolybdate-based HER electrocatalysts because all reported TOF values up to date concern catalysts supported on surfaces other than semiconductors. Additionally, a few studies devoted to other molecular HER electrocatalysts 

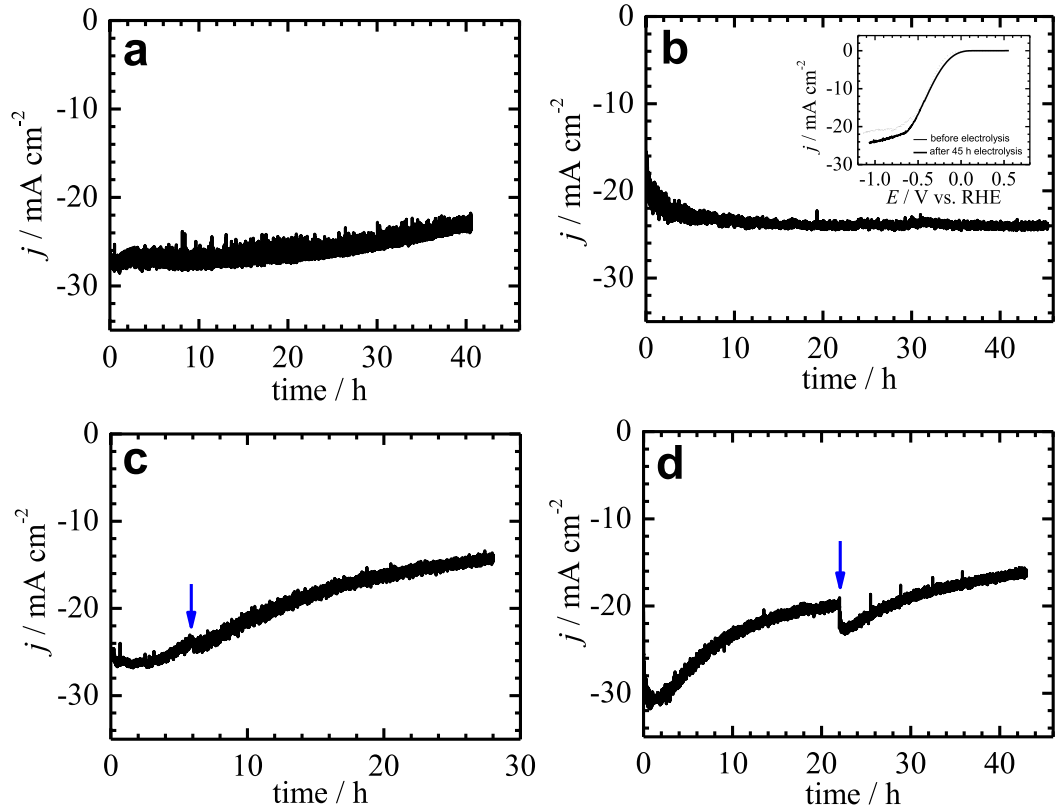

Figure 8. Long-term stability of the optimized $\mathrm{Mo}_{3} \mathrm{~S}_{4}(\mathrm{acac}-\mathrm{Bu})(\mathrm{a}, \mathrm{c})$ and $\mathrm{Mo}_{3} \mathrm{~S}_{4}\left(\mathrm{AsW}_{12}\right)(\mathrm{b}, \mathrm{d})$-modified photocathodes for simulated sunlightdriven HER during the controlled potential electrolysis at $-0.84 \mathrm{~V}$ vs RHE in a $\mathrm{pH} 0.3$ solution $(\mathrm{a}, \mathrm{b})$ or $-1.04 \mathrm{~V}$ vs $\mathrm{RHE}$ in a $\mathrm{pH} 7.3$ solution $(\mathrm{c}, \mathrm{d})$. (Inset) $i R$-uncorrected LSV curves at $20 \mathrm{mV} \mathrm{s}^{-1}\left(\mathrm{pH} 0.3\right.$ ) of the $\mathrm{Mo}_{3} \mathrm{~S}_{4}\left(\mathrm{AsW}_{12}\right)$-modified photocathode before and after electrolysis. The blue arrows indicate the removal of the $\mathrm{H}_{2}$ bubbles from the surface.

attached to p-type semiconductors have reported an order of magnitude lower TOFs. For instance, metalloporphyrin covalently bound to p-type GaP yielded a TOF of ca. $4 \mathrm{~s}^{-1}$ at $0 \mathrm{~V}$ versus $\mathrm{RHE}$ and $\mathrm{pH} 7$ under identical illumination conditions. ${ }^{64}$ In another example, a cobalt molecular complex bound to a $\mathrm{TiO}_{2}$-protected $\mathrm{GaInP}_{2}$ photocathode produced $\mathrm{H}_{2}$ with a TOF of $3.4 \mathrm{~s}^{-1}$ at $0 \mathrm{~V}$ versus RHE but under basic conditions ( $\mathrm{pH} \mathrm{13}) .{ }^{65}$ Besides the possible underestimation of the density of catalytically active sites, the high TOF values reported in this work may also be due to a significant contribution of the silicon surface in the catalytic process even though special care has been taken to measure accurately the TOF of the alone immobilized catalyst (restricted potential range in which the current densities are expected to be controlled by the HER kinetics and the use of high concentration of the electrolyte).

2.5. Long-Term Stability of the Photocathodes. The stability criterion is another crucial requirement for modified photocathodes, mainly driven by the robustness of the interface. To assess the long-term stability of our photocathodes, controlled potential electrolyses were carried out in both aqueous solutions over testing periods exceeding ca. $30 \mathrm{~h}$.

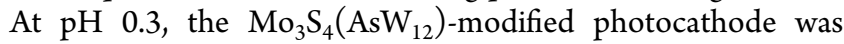
found to be the most robust because no noticeable decrease in the photocurrent was observed after $40 \mathrm{~h}$. In contrast, a $18 \%$ decrease in the cathodic photocurrent was measured for the $\mathrm{Mo}_{3} \mathrm{~S}_{4}$ (acac-Bu)-modified photocathode (Figure 8). Such a trend features the high stability of the $\mathrm{Mo}_{3} \mathrm{~S}_{4}\left(\mathrm{AsW}_{12}\right)$ POM material functioning under acidic conditions. The similarity between the LSV curves before and after electrolysis supports the excellent stability of the $\mathrm{Mo}_{3} \mathrm{~S}_{4}\left(\mathrm{AsW}_{12}\right)$-modified photocathode. At $\mathrm{pH}$ 7.3, in line with short-term stability tests detailed in the previous section, both photocathodes were found to be much less stable during the potentiostatic electrolysis with a comparable decrease in the photocurrent after $30 \mathrm{~h}$, namely, $38 \%$ against $45 \%$. We believe that the lower stability and lower activity observed at $\mathrm{pH} 7.3$ for both modified photocathodes can be ascribed to some decomposition reactions of the immobilized catalysts and/or a different $\mathrm{Si}$ chemical interface. In the case of the $\mathrm{Mo}_{3} \mathrm{~S}_{4}$ (acac$\mathrm{Bu}$ ) catalyst, the first process may originate from the substitution of the organic ligand by some anions from the electrolyte, whereas a hydrolytic decomposition leading to the transformation (such as partial decondensation) of the $\left\{\mathrm{Mo}_{3} \mathrm{~S}_{4}-\mathrm{POM}\right\}$ hybrid material is possible in the case of the second catalyst. ${ }^{31,66}$ The second process associated to the electrode may lead to the gradual degradation of the $\mathrm{Si} /$ catalyst interface or could enhance catalyst desorption. ${ }^{67}$

\section{CONCLUSIONS}

In this work, we have demonstrated that a p-type silicon photocathode coated with a polyoxothiometalate electrocatalyst was catalytically more efficient than a photocathode coated with the parent thiomolybdate incorporating an organic ligand for the simulated sunlight-driven HER under acid $\mathrm{pH}$ conditions. These findings were supported by a higher onset potential and a lower overvoltage at $10 \mathrm{~mA} \mathrm{~cm}{ }^{-2}$, in spite of a ca. 4-7 times smaller catalyst coverage. Under such conditions, the polyoxothiometalate-modified photocathode produced $\mathrm{H}_{2}$ quantitatively with a promising stability along 40 $\mathrm{h}$ controlled potential electrolysis tests. In contrast, the photocurrents measured at a thiomolybdate-modified surface were gradually ca. $20 \%$ decreased under the same conditions. At neutral $\mathrm{pH}$, the situation was inversed and the beneficial effect of the POM for the HER was not observed.

It is anticipated that the catalytic performance of our electrodes could be improved by using Si-structured surfaces incorporating an additional $\mathrm{n}^{+}$Si layer on the $\mathrm{p}$-type Si surface of the photocathode structure, as recently proposed for CoPcoated HER photocathodes. ${ }^{68}$ Moreover, very rich chemistries of POMs and chalcogenide clusters are also promising directions to improve further HER activity of this new class 
of $\mathrm{Mo}_{3} \mathrm{~S}_{4}-\mathrm{POM}$ electrocatalysts. ${ }^{69,70}$ Finally, because of their high metal nuclearity, POMs represent relevant molecular systems for multielectron transfer engineering and then ideal candidates to tackle the challenging electrocatalytic process of great societal interest, namely, the $\mathrm{CO}_{2}$ reduction.

\section{EXPERIMENTAL SECTION}

4.1. Reagents. Acetone (MOS electronic grade, Erbatron from Carlo Erba), anhydrous ethanol (RSE electronic grade, Erbatron from Carlo Erba), and 3-butylpentane-2,4-dione (Sigma-Aldrich) were used without further purification. The cationic cluster $\left\{\mathrm{Mo}_{3} \mathrm{~S}_{4}\right\}^{4+}$ was prepared through a previously reported procedure ${ }^{71}$ and available in the solid state as $\left(\mathrm{NH}_{4}\right)_{2} \mathrm{Mo}_{3} \mathrm{~S}_{4}\left(\mathrm{H}_{2} \mathrm{O}\right)_{9} \mathrm{Cl}_{6} \cdot 3 \mathrm{H}_{2} \mathrm{O}$. The chemicals used for the cleaning and etching of silicon wafer pieces $\left(30 \% \mathrm{H}_{2} \mathrm{O}_{2}, 96-\right.$ $97 \% \mathrm{H}_{2} \mathrm{SO}_{4}$ and $50 \%$ HF solutions) were of VLSI $\left(\mathrm{H}_{2} \mathrm{O}_{2}\right.$, from Sigma-Aldrich) and MOS $\left(\mathrm{H}_{2} \mathrm{SO}_{4}\right.$ from O-BASF and $\mathrm{HF}$ from Sigma-Aldrich) semiconductor grade.

4.2. Syntheses of the Compounds. 4.2.1. $\left[\mathrm{Mo}_{3} \mathrm{~S}_{4}\right.$ (acac$\left.\mathrm{Bu})_{3}\left(\mathrm{H}_{2} \mathrm{O}\right)_{3}\right] \mathrm{Cl} \cdot \mathrm{H}_{2} \mathrm{O} . \quad\left(\mathrm{NH}_{4}\right)_{2} \mathrm{Mo}_{3} \mathrm{~S}_{4}\left(\mathrm{H}_{2} \mathrm{O}\right)_{9} \mathrm{Cl}_{6} \cdot 3 \mathrm{H}_{2} \mathrm{O} \quad(1.0 \mathrm{~g}$; $1.13 \mathrm{mmol}$ ) was dissolved in methanol (30 mL). 3Butylpentane-2,4-dione (noted acac-Bu) (0.695 g; 4.45 $\mathrm{mmol}$ ) and $2.2 \mathrm{~mL}$ of $1 \mathrm{~mol} \mathrm{~L}{ }^{-1} \mathrm{KOH}$ aqueous solution were mixed in $5 \mathrm{~mL}$ of methanol and then slowly added to the greenish $\left\{\mathrm{Mo}_{3} \mathrm{~S}_{4}\right\}$-containing solution. The resulting darkgreen solution was allowed to stand for crystallization. After 2 days, well-shaped parallelepipedic crystals suitable for X-ray diffraction analysis were collected. Yield: $0.66 \mathrm{~g}$ (60\% vs Mo). ${ }^{1} \mathrm{H}$ NMR (300 MHz, MeOD): $\delta$ (ppm) $8.89(\mathrm{t}, 3 \mathrm{H}), 1.29(2$ $\times 2 \mathrm{H}), 2.11 \mathrm{ppm}(6 \mathrm{H}), 2.29(2 \mathrm{H})$. Anal. Calcd for $\mathrm{Mo}_{3} \mathrm{~S}_{4} \mathrm{C}_{29} \mathrm{H}_{55} \mathrm{O}_{10} \mathrm{Cl}$ : Mo, 0.28; S, 0.12; C, 0.33; H, 0.054; Cl, 0.03. Found: $\mathrm{Mo}, 0.27 ; \mathrm{S}, 0.11 ; \mathrm{C}, 0.36 ; \mathrm{H}, 0.058 ; \mathrm{Cl}, 0.03$.

4.2.2. $\mathrm{Rb}_{3} \mathrm{NaHAsW}_{12} \mathrm{Mo}_{3} \mathrm{~S}_{4}\left(\mathrm{H}_{2} \mathrm{O}\right)_{3} \mathrm{O}_{42} \cdot 14 \mathrm{H}_{2} \mathrm{O}$. Sodium tungstate dihydrate $\mathrm{Na}_{2} \mathrm{WO}_{4} \cdot 2 \mathrm{H}_{2} \mathrm{O}(1.11 \mathrm{~g} ; 3.36 \mathrm{mmol})$ and $\mathrm{Na}_{9} \mathrm{AsW}_{9} \mathrm{O}_{33} \cdot 12 \mathrm{H}_{2} \mathrm{O}(3.0 \mathrm{~g} ; 1.12 \mathrm{mmol})$ were suspended in 30 $\mathrm{mL}$ of water and acidified by $3.5 \mathrm{~mL}$ of aqueous solution of 2 mol L ${ }^{-1}$ hydrochloric acid until $\mathrm{pH}$ was down to about $\mathrm{pH}=5$. The resulting solution was then heated at $50{ }^{\circ} \mathrm{C}$ while $10 \mathrm{~mL}$ of aqueous solution containing $\left(\mathrm{NH}_{4}\right)_{2} \mathrm{Mo}_{3} \mathrm{~S}_{4}\left(\mathrm{H}_{2} \mathrm{O}\right)_{9} \mathrm{Cl}_{6}$. $3 \mathrm{H}_{2} \mathrm{O}$ (1.0 g; $1.13 \mathrm{mmol}$ ) was slowly added drop by drop under gentle stirring. A cloudy brownish precipitate was formed and disappeared slowly after $30 \mathrm{~min}$ at $50^{\circ} \mathrm{C}$. The $\mathrm{pH}$ of the solution was 2.3. After the solution cooled down to room temperature, rubidium chloride ( $1.5 \mathrm{~g} ; 12 \mathrm{mmol})$ was poured to the solution provoking the formation of a darkbrown solid. After $30 \mathrm{~min}$ under slow stirring, the solid was then collected through filtration using a glass frit filter, washed with ethanol, and dried using diethyl ether. Analysis of the resulting solid $(2.8 \mathrm{~g})$ was consistent with $\mathrm{Rb}_{3} \mathrm{NaHAsW} \mathrm{Na}_{12} \mathrm{Mo}_{3} \mathrm{~S}_{4}\left(\mathrm{H}_{2} \mathrm{O}\right)_{3} \mathrm{O}_{42} \cdot 14 \mathrm{H}_{2} \mathrm{O}$, leading to a yield of about $65 \%$. Anal. Calcd for $\mathrm{Rb}_{3} \mathrm{NaH}_{35} \mathrm{AsW}_{12} \mathrm{Mo}_{3} \mathrm{~S}_{4} \mathrm{O}_{59}: \mathrm{Rb}$, 6.5; Na, 0.6; As, 1.9; W, 55.7; Mo, 7.3; S, 3.2. Found: Rb, 6.6; $\mathrm{Na}, 0.55$; As, 1.8 ; W, 55.7; Mo, 7.2; S, 3.3. Thermal gravimetric analysis (TGA): weight loss of $8 \%$ between RT and $200{ }^{\circ} \mathrm{C}$ corresponding to 17.5 water molecules distributed as 14 crystallization water molecules and 3 aquo ligands attached to the $\left\{\mathrm{Mo}_{3} \mathrm{~S}_{4}\right\}$ core and $1 / 2$ constitutional water. IR $\left(\mathrm{cm}^{-1}\right)$ : 950(s), 847(m), 780(vs), 656(w), 445(w).

4.2.3. $\left[\left(n-\mathrm{C}_{6} \mathrm{H}_{13}\right)_{4} \mathrm{~N}\right]_{5} \mathrm{AsW}_{12} \mathrm{Mo}_{3} \mathrm{~S}_{4}\left(\mathrm{H}_{2} \mathrm{O}\right)_{3} \mathrm{O}_{42}$. The cationic exchange has been carried out through liquid-liquid extraction of the POM as an alkali salt from the aqueous solution to the toluene organic phase containing tetra- $n$-hexylammonium bromide. The $50 \mathrm{~mL}$ aqueous solution contained $2.55 \mathrm{mmol}$
$\mathrm{L}^{-1}$ in $\mathrm{Rb}_{3} \mathrm{NaHAsW}_{12} \mathrm{Mo}_{3} \mathrm{~S}_{4}\left(\mathrm{H}_{2} \mathrm{O}\right)_{3} \mathrm{O}_{42} \cdot 14 \mathrm{H}_{2} \mathrm{O}$, whereas the organic phase corresponded to tetrahexylammonium bromide (0.40 g; $0.92 \mathrm{mmol}$ ) dissolved in $40 \mathrm{~mL}$ of toluene. Both solutions were contacted vigorously for $30 \mathrm{~min}$ and then decanted within a separatory funnel. The brownish organic phase was collected. The solvent was removed through a rotary evaporator until obtaining a dark-brown oily residue which was thoroughly washed with ethanol and diethylether. Yield: 340 mg (46\%). Anal. Calcd for C, 27.7; H, 5.0; N, 0.9. Found: C, 28.3; H, 5.1; N, 1.1; EDX atomic ratios. Calcd (found): W/Mo $=4(3.9) ; \mathrm{W} / \mathrm{S}=3(2.8)$. TGA: weight loss of $35 \%$ between RT and $500{ }^{\circ} \mathrm{C}$ in agreement with the combustion of five tetra- $n$ hexylammonium units. IR $\left(\mathrm{cm}^{-1}\right)$ : 957(s); 850(m); 797(vs); $729(\mathrm{sh})$.

4.3. Analytical Methods for Characterization of the Precursors. The NMR spectra were measured in $\mathrm{D}_{2} \mathrm{O}$ at 27 ${ }^{\circ} \mathrm{C}$. ${ }^{1} \mathrm{H}$ and ${ }^{183} \mathrm{~W}$ NMR spectra were recorded on a Bruker AVANCE 500 spectrometer at 500.1 and $20.84 \mathrm{MHz}$, respectively. According to conventions for standards, chemical shifts are referenced with respect to TMS and $1 \mathrm{M} \mathrm{Na}_{2} \mathrm{WO}_{4}$ aqueous solution for ${ }^{1} \mathrm{H}$ and ${ }^{183} \mathrm{~W}$, respectively.

Fourier transform infrared (FT-IR) spectra were recorded on a 6700 FT-IR Nicolet spectrophotometer, using the diamond attenuated total reflection (ATR) technique. The spectra were recorded on nondiluted compounds in the range $400-4000 \mathrm{~cm}^{-1}$. ATR correction was applied.

UV-vis spectra of powdered compounds have been collected by using a PerkinElmer LAMBDA 750 spectrophotometer equipped with a powder sample holder set. The UVvis spectra of solutions were recorded on PerkinElmer LAMBDA-750 using a calibrated $0.1 \mathrm{~cm}$ quartz-cell.

Energy-dispersive X-ray spectra were obtained using a scanning electron microscope enhanced by a field emission gun equipment (JSM 7001-F, JEOL). The measurements were acquired with a SDD X-Max $50 \mathrm{~mm}^{2}$ detector and the Aztec (Oxford) system working at $15 \mathrm{kV}$ and $10 \mathrm{~mm}$ distance. The quantification is realized with the standard library provided by the constructor using $\mathrm{L} \alpha$ lines.

The number of water molecules and tetra- $n$-hexylammonium cations were determined by TGA with a Mettler Toledo TGA/ differential scanning calorimetry $1, \mathrm{STAR}^{\mathrm{e}}$ System apparatus or with a NETZSCH TG $209 \mathrm{~F} 1$ device under air flow $(50 \mathrm{~mL}$ $\min ^{-1}$ ) at a heating rate of $5{ }^{\circ} \mathrm{C} \min ^{-1}$ up to $800{ }^{\circ} \mathrm{C}$.

4.4. Single-Crystal X-ray Diffraction Study. Intensity data collections were carried out at $T=200(2) \mathrm{K}$ with a Bruker X8 APEX2 charge-coupled device, using the MoK $\alpha$ wavelength $(\lambda=0.71073 \AA)$. The crystals were glued in paratone to prevent any loss of solvent. An empirical absorption correction was applied using the SADABS program ${ }^{72}$ based on the method of Blessing. ${ }^{93}$ The structures were solved by direct methods and refined by full-matrix least squares using the SHELX-TL package. ${ }^{74}$ Heavier atoms (Mo) were initially located by direct methods. The remaining nonhydrogen atoms were located from Fourier differences and were refined with anisotropic thermal parameters. Positions of the hydrogen atoms belonging to the organic ligand Acac-Bu were calculated and refined isotropically using the gliding mode. Data collection, structure refinement details, and crystallographic data for the single-crystal X-ray diffraction study of 1 can be found in Table S1 (Supporting Information), including the CIF file. CCDC 1854697 also contains the supplementary crystallographic data, which can be obtained free of charge via www.ccdc.cam.ac.uk/data_request/cif. 
4.5. Preparation of the Modified Silicon Surfaces. A piece of p-type (1-5 $\Omega \mathrm{cm}$ resistivity, boron-doped, $250 \mu \mathrm{m}$ thickness, Siltronix $)$ or $\mathrm{n}^{+}$-type $(0.001 \Omega \mathrm{cm}$ resistivity, phosphorus-doped, $250 \mu \mathrm{m}$ thickness, Siltronix) Si(100) was sonicated for $10 \mathrm{~min}$ successively in acetone, ethanol, and ultrapure 18.2 $\mathrm{M} \Omega \mathrm{cm}$ water (Veolia Water STI) to degrease it. It was then cleaned with piranha solution $(3: 1 \mathrm{v} / \mathrm{v}$ concentrated $\left.\mathrm{H}_{2} \mathrm{SO}_{4} / 30 \% \mathrm{H}_{2} \mathrm{O}_{2}\right)$ for $30 \mathrm{~min}$ at $100{ }^{\circ} \mathrm{C}$, followed by copious rinsing with ultrapure water to eliminate heavy metals and organic residues.

Caution: The concentrated aqueous $\mathrm{H}_{2} \mathrm{SO}_{4} / \mathrm{H}_{2} \mathrm{O}_{2}$ (piranha) solution is highly dangerous, particularly in contact with organic materials and should be handled extremely carefully.

For electrochemical measurements, the decontaminated surface was further processed to fabricate the photocathode. An Ohmic contact was established on the backside Si surface with a metal wire by first scrubbing the surface with sand paper and a diamond glass cutter and then applying a droplet of InGa eutectic (99.99\%, Alfa Aesar). A layer of silver paste (Electron Microscopy Sciences) was then deposited on the contact. After drying of the silver paste, the metal wire was inserted in a glass capillary, and the electrode area $\left(0.20-0.45 \mathrm{~cm}^{2}\right)$ was defined with an epoxy-based resin (LOCTITE 9460, Henkel) that covered all of the back of the Si surface as well as the silver paste. The assembled electrode was then placed into an oven at $90{ }^{\circ} \mathrm{C}$ overnight to cure the resin.

The silicon surface sealed in epoxy was freshly hydrogenated by immersing the electrode into HF $10 \%$ wt $(\sim 5.7 \mathrm{M})$ for 2 min, followed by copious rinsing with ultrapure water and drying under an argon stream.

Caution: Proper precautions must be used when handling hydrogen fluoride. Hydrogen fluoride is extremely corrosive for human tissue, contact resulting in painful, slow-healing burns. Laboratory work with HF should be conducted only in an efficient hood, with the operator wearing a full-face shield and protective clothing.

The cluster solution was prepared at $1 \mathrm{mM}$ in methanol (CHROMASOLV, for high-pressure liquid chromatography, $\geq 99.9 \%)$ by dissolving $\left[\mathrm{Mo}_{3} \mathrm{~S}_{4}(\mathrm{acac}-\mathrm{Bu})_{3}\left(\mathrm{H}_{2} \mathrm{O}\right)_{3}\right] \mathrm{Cl} \cdot \mathrm{H}_{2} \mathrm{O}$ or $\left[\left(n-\mathrm{C}_{6} \mathrm{H}_{13}\right)_{4} \mathrm{~N}\right]_{5} \mathrm{AsW}_{12} \mathrm{Mo}_{3} \mathrm{~S}_{4}\left(\mathrm{H}_{2} \mathrm{O}\right)_{3} \mathrm{O}_{42}$ followed by sonication for ca. $15 \mathrm{~min}$. The solution was then diluted with methanol to reach the final concentration of 0.5 or $0.1 \mathrm{mM}$. The freshly hydrogenated $\mathrm{Si}(100)$ surface was modified with the $\mathrm{Mo}_{3} \mathrm{~S}_{4}(\mathrm{acac}-\mathrm{Bu})$ or $\mathrm{Mo}_{3} \mathrm{~S}_{4}\left(\mathrm{AsW}_{12}\right)$ cluster by drop-casting of the $\left[\mathrm{Mo}_{3} \mathrm{~S}_{4}(\mathrm{acac}-\mathrm{Bu})_{3}\left(\mathrm{H}_{2} \mathrm{O}\right)_{3}\right] \mathrm{Cl} \cdot \mathrm{H}_{2} \mathrm{O}$ or $[(n-$ $\left.\left.\mathrm{C}_{6} \mathrm{H}_{13}\right)_{4} \mathrm{~N}\right]_{5} \mathrm{AsW}_{12} \mathrm{Mo}_{3} \mathrm{~S}_{4}\left(\mathrm{H}_{2} \mathrm{O}\right)_{3} \mathrm{O}_{42}$ solution at $0.1,0.5$, or 1 $\mathrm{mM}$ in methanol, yielding cluster loading values of $7.2 \times 10^{-6}$, $3.6 \times 10^{-5}$, or $7.2 \times 10^{-5} \mathrm{mmol} \mathrm{cm}{ }^{-2}$, respectively. The modified photocathodes were further used for electrochemical measurements after evaporation of the solvent at room temperature for 5-10 min.

4.6. Electrochemical Measurements. LSV measurements were performed in a homemade three-neck cell comprising a quartz window in which were inserted a $\mathrm{KCl}$ saturated calomel reference electrode (SCE) and a glassy carbon counter electrode (the counter electrode was separated from the rest of the cell by a glass frit). The cell was filled with the electrolytic solution containing either $1.0 \mathrm{~mol} \mathrm{~L}^{-1} \mathrm{H}_{2} \mathrm{SO}_{4}$ ( $\mathrm{pH} 0.3$ ) or $0.1 \mathrm{~mol} \mathrm{~L}^{-1} \mathrm{KCl}+0.5 \mathrm{~mol} \mathrm{~L}^{-1} \mathrm{KHCO}_{3}(\mathrm{pH} \mathrm{7.3)}$ and was deaerated by bubbling Ar for at least $30 \mathrm{~min}$ prior to experiments. The photocathode (hydrogen-terminated p-type $\mathrm{Si}(100)$ or freshly covered by the metallic cluster using the protocol described above) was disposed in front of the quartz window and used as a working electrode. The light was provided by a solar simulator with a fluence of $100 \mathrm{~mW} \mathrm{~cm}^{-2}$ (LS0106, LOT Quantum Design) equipped with an AM 1.5G filter. Electrochemical measurements were performed with potentiostat/galvanostat Autolab PGSTAT 302N (Eco Chemie BV) equipped with the GPES and FRA softwares. LSV curves were recorded at $20 \mathrm{mV} \mathrm{s}^{-1}$. Unless specified, all of the LSV curves and the reported potentials were intentionally not corrected by the Ohmic drop. The Ohmic drop was determined before each experiment by measuring the impedance of the system at $100 \mathrm{kHz}$, and it was found to be around 20-100 $\Omega$ depending on the type of the tested photoelectrode and the used electrolytic medium. The geometrical areas of the electrodes used for LSV were in the range $0.20-0.45 \mathrm{~cm}^{2}$, and their exact value was measured using the ImageJ software to calculate the current densities. Potentials versus SCE was converted into potential versus RHE using the equation: $E_{\mathrm{RHE}}=E_{\mathrm{SCE}}+0.24+0.059 \times \mathrm{pH}$ (that was experimentally verified in our operating conditions with a bare platinum electrode). The preparative-scale electrolysis was performed in a Hoffman cell comprising a quartz window and two closed graduated cylinders above the working electrode and the counter electrode. The volumes of $\mathrm{H}_{2}$ and $\mathrm{O}_{2}$ gases were measured in situ during the electrolysis; more details can be found in ref 59. For the determination of the Faradaic yield, the theoretical volume of produced $\mathrm{H}_{2}$ $\left(V_{\mathrm{H}_{2}}^{\mathrm{T}}\right)$ was calculated using the electrical charge used during the electrolysis using the following equation

$$
V_{\mathrm{H}_{2}}^{\mathrm{T}}=\left(\frac{Q}{2 F}\right) \times\left(\frac{R T}{P}\right)
$$

with $Q$ being the charge passed during the electrolysis, $F$ being the Faraday constant, $R$ being the gas constant, $T$ being the ambient temperature, and $P$ being the atmospheric pressure.

4.7. Additional Instrumentation. XPS measurements were performed with a $\mathrm{Mg} \mathrm{K} \alpha 1254 \mathrm{eV}$ X-ray source, using a VSW HA100 photoelectron spectrometer with a hemispherical photoelectron analyzer, working at an energy pass of $20 \mathrm{eV}$ for survey and resolved spectra. The experimental resolution was then $1.0 \mathrm{eV}$. The binding energy for the main $\mathrm{C}-\mathrm{C}$ peak has been taken at $285.0 \mathrm{eV}$ as an internal reference level for all measurements. Spectral analysis included a Shirley background subtraction and peak separation using mixed GaussianLorentzian functions.

AFM images were acquired on a NT-MDT NTEGRA microscope in semicontact mode with FM tips (resonance frequency around $60 \mathrm{kHz}$ ). The images were treated and analyzed with the open-source Gwyddion software.

\section{ASSOCIATED CONTENT}

\section{Supporting Information}

The Supporting Information is available free of charge on the ACS Publications website at DOI: 10.1021/acsomega.8b01734.

Crystallographic data for $\left[\mathrm{Mo}_{3} \mathrm{~S}_{4}(\text { acac- } \mathrm{Bu})_{3}\left(\mathrm{H}_{2} \mathrm{O}\right)_{3}\right] \mathrm{Cl}$. $\mathrm{H}_{2} \mathrm{O}$; spectroscopic characterization of $\mathrm{Mo}_{3} \mathrm{~S}_{4}-\mathrm{POM}$; supplementary voltammograms and XPS spectra; supplementary AFM images of the modified surfaces; calculation methods of the cluster surface coverage; and determination of the TOF (PDF)

Crystallographic data for the single-crystal X-ray diffraction study of $\mathbf{1}$ (CIF) 


\section{AUTHOR INFORMATION}

\section{Corresponding Authors}

*E-mail: fabre@univ-rennes1.fr (B.F.).

*E-mail: emmanuel.cadot@uvsq.fr (E.C.).

\section{ORCID $\odot$}

Bruno Fabre: 0000-0002-0488-7812

Gabriel Loget: 0000-0003-4809-5013

Emmanuel Cadot: 0000-0003-4136-6298

Notes

The authors declare no competing financial interest.

\section{ACKNOWLEDGMENTS}

The authors gratefully acknowledge ANR (Agence Nationale de la Recherche) for financial support of the CHALCO-CAT program (CHALCO-CAT ANR-15-CE06-0002-01). This work was supported by (i) University of Rennes 1, (ii) University of Versailles Saint Quentin, (iii) CNRS and (iv) the LabEx CHARMMMAT of University Paris-Saclay (grant number ANR-11-LABX-0039).

\section{REFERENCES}

(1) Cook, T. R.; Dogutan, D. K.; Reece, S. Y.; Surendranath, Y.; Teets, T. S.; Nocera, D. G. Solar Energy Supply and Storage for the Legacy and Nonlegacy Worlds. Chem. Rev. 2010, 110, 6474-6502.

(2) Lewis, N. S.; Nocera, D. G. Powering the Planet: Chemical Challenges in Solar Energy Utilization. Proc. Natl. Acad. Sci. U.S.A. 2006, 103, 15729-15735.

(3) Walter, M. G.; Warren, E. L.; McKone, J. R.; Boettcher, S. W.; Mi, Q.; Santori, E. A.; Lewis, N. S. Solar Water Splitting Cells. Chem. Rev. 2010, 110, 6446-6473.

(4) Zhang, X. G. Electrochemistry of Silicon and Its Oxide; Kluwer Academic Publishers: New York, 2004.

(5) Sivula, K.; van de Krol, R. Semiconducting Materials for Photoelectrochemical Energy Conversion. Nat. Rev. Mater. 2016, 1, 15010 .

(6) Sun, K.; Shen, S.; Liang, Y.; Burrows, P. E.; Mao, S. S.; Wang, D. Enabling Silicon for Solar-Fuel Production. Chem. Rev. 2014, 114, 8662-8719.

(7) Wrighton, M. S. Thermodynamics and Kinetics Associated with Semiconductor-Based Photoelectrochemical Cells for the Conversion of Light to Chemical Energy. Pure Appl. Chem. 1985, 57, 57-68.

(8) Boettcher, S. W.; Warren, E. L.; Putnam, M. C.; Santori, E. A.; Turner-Evans, D.; Kelzenberg, M. D.; Walter, M. G.; McKone, J. R.; Brunschwig, B. S.; Atwater, H. A.; Lewis, N. S. Photoelectrochemical Hydrogen Evolution Using Si Microwire Arrays. J. Am. Chem. Soc. 2011, 133, 1216-1219.

(9) Dai, P.; Xie, J.; Mayer, M. T.; Yang, X.; Zhan, J.; Wang, D. Solar Hydrogen Generation by Silicon Nanowires Modified with Platinum Nanoparticle Catalysts by Atomic Layer Deposition. Angew. Chem., Int. Ed. 2013, 52, 11119-11123.

(10) Fabre, B.; Li, G.; Gouttefangeas, F.; Joanny, L.; Loget, G. Tuning the Photoelectrocatalytic Hydrogen Evolution of PtDecorated Silicon Photocathodes by the Temperature and Time of Electroless Pt Deposition. Langmuir 2016, 32, 11728-11735.

(11) Truong, T.-G.; Mériadec, C.; Fabre, B.; Bergamini, J.-F.; de Sagazan, O.; Ababou-Girard, S.; Loget, G. Spontaneous Decoration of Silicon Surfaces with $\mathrm{MoO}_{\mathrm{x}}$ Nanoparticles for the Sunlight-Assisted Hydrogen Evolution Reaction. Nanoscale 2017, 9, 1799-1804.

(12) Bao, X.-Q.; Petrovykh, D. Y.; Alpuim, P.; Stroppa, D. G.; Guldris, N.; Fonseca, H.; Costa, M.; Gaspar, J.; Jin, C.; Liu, L. Amorphous Oxygen-Rich Molybdenum Oxysulfide Decorated p-Type Silicon Microwire Arrays for Efficient Photoelectrochemical Water Reduction. Nano Energy 2015, 16, 130-142.

(13) Hou, Y.; Abrams, B. L.; Vesborg, P. C. K.; Björketun, M. E.; Herbst, K.; Bech, L.; Setti, A. M.; Damsgaard, C. D.; Pedersen, T.; Hansen, O.; Rossmeisl, J.; Dahl, S.; Nørskov, J. K.; Chorkendorff, I.
Bioinspired Molecular Co-Catalysts Bonded to a Silicon Photocathode for Solar Hydrogen Evolution. Nat. Mater. 2011, 10, 434438.

(14) Seger, B.; Herbst, K.; Pedersen, T.; Abrams, B.; Vesborg, P. C. K.; Hansen, O.; Chorkendorff, I. $\mathrm{Mo}_{3} \mathrm{~S}_{4}$ Clusters as an Effective $\mathrm{H}_{2}$ Evolution Catalyst on Protected Si Photocathodes. J. Electrochem. Soc. 2014, 161, H722-H724.

(15) Seger, B.; Laursen, A. B.; Vesborg, P. C. K.; Pedersen, T.; Hansen, O.; Dahl, S.; Chorkendorff, I. Hydrogen Production Using a Molybdenum Sulfide Catalyst on a Titanium-Protected $\mathrm{n}+\mathrm{p}$-Silicon Photocathode. Angew. Chem., Int. Ed. 2012, 51, 9128-9131.

(16) Laursen, A. B.; Pedersen, T.; Malacrida, P.; Seger, B.; Hansen, O.; Vesborg, P. C. K.; Chorkendorff, I. $\mathrm{MoS}_{2}$-an Integrated Protective and Active Layer on $\mathrm{n}+\mathrm{p}-\mathrm{Si}$ for Solar $\mathrm{H}_{2}$ Evolution. Phys. Chem. Chem. Phys. 2013, 15, 20000-20004.

(17) Morales-Guio, C. G.; Hu, X. Amorphous Molybdenum Sulfides as Hydrogen Evolution Catalysts. Acc. Chem. Res. 2014, 47, 26712681.

(18) Tran, P. D.; Pramana, S. S.; Kale, V. S.; Nguyen, M.; Chiam, S. Y.; Batabyal, S. K.; Wong, L. H.; Barber, J.; Loo, J. Novel Assembly of an $\mathrm{MoS}_{2}$ Electrocatalyst onto a Silicon Nanowire Array Electrode to Construct a Photocathode Composed of Elements Abundant on the Earth for Hydrogen Generation. Chem.-Eur. J. 2012, 18, 1399413999.

(19) Ding, Q.; Meng, F.; English, C. R.; Cabán-Acevedo, M.; Shearer, M. J.; Liang, D.; Daniel, A. S.; Hamers, R. J.; Jin, S. Efficient Photoelectrochemical Hydrogen Generation Using Heterostructures of $\mathrm{Si}$ and Chemically Exfoliated Metallic $\mathrm{MoS}_{2}$. J. Am. Chem. Soc. 2014, 136, 8504-8507.

(20) Ding, Q.; Zhai, J.; Cabán-Acevedo, M.; Shearer, M. J.; Li, L.; Chang, H.-C.; Tsai, M.-L.; Ma, D.; Zhang, X.; Hamers, R. J.; He, J.H.; Jin, S. Designing Efficient Solar-Driven Hydrogen Evolution Photocathodes Using Semitransparent $\mathrm{MoQ}_{\mathrm{x}} \mathrm{Cl}_{\mathrm{y}}(\mathrm{Q}=\mathrm{S}, \mathrm{Se})$ Catalysts on Si Micropyramids. Adv. Mater. 2015, 27, 6511-6518.

(21) Benck, J. D.; Lee, S. C.; Fong, K. D.; Kibsgaard, J.; Sinclair, R.; Jaramillo, T. F. Designing Active and Stable Silicon Photocathodes for Solar Hydrogen Production Using Molybdenum Sulfide Nanomaterials. Adv. Energy Mater. 2014, 4, 1400739.

(22) King, L. A.; Hellstern, T. R.; Park, J.; Sinclair, R.; Jaramillo, T. F. Highly Stable Molybdenum Disulfide Protected Silicon Photocathodes for Photoelectrochemical Water Splitting. ACS Appl. Mater. Interfaces 2017, 9, 36792-36798.

(23) McCrory, C. C. L.; Jung, S.; Ferrer, I. M.; Chatman, S. M.; Peters, J. C.; Jaramillo, T. F. Benchmarking Hydrogen Evolving Reaction and Oxygen Evolving Reaction Electrocatalysts for Solar Water Splitting Devices. J. Am. Chem. Soc. 2015, 137, 4347-4357.

(24) Llusar, R.; Uriel, S. Heterodimetallic Chalcogen-Bridged Cubane-Type Clusters of Molybdenum and Tungsten Containing First-Row Transition Metals. Eur. J. Inorg. Chem. 2003, 1271-1290.

(25) Pino-Chamorro, J. A.; Gushchin, A. L.; Fernández-Trujillo, M. J.; Hernández-Molina, R.; Vicent, C.; Algarra, A. G.; Basallote, M. G. Mechanism of [3+2] Cycloaddition of Alkynes to the $\left[\mathrm{Mo}_{3} \mathrm{~S}_{4}(\mathrm{acac})_{3}(\mathrm{py})_{3}\right]\left[\mathrm{PF}_{6}\right]$ Cluster. Chem.-Eur. J. 2015, 21, 28352844.

(26) Duval, S.; Dumur, F.; Guénée, L.; Marrot, J.; Simonnet-Jégat, C.; Cadot, E. Synthesis and Characterization of $\left[\mathrm{Mo}_{3} \mathrm{~S}_{4}(\mathrm{NDABu})\right.$ $\left.(\mathrm{HNDABu})_{2}\right]^{3-}$ and $\left[\mathrm{Mo}_{3} \mathrm{~S}_{4}(\mathrm{HNDAPr})_{3}\right]^{2-}$ Anions as Building Blocks for Organic-Inorganic Hybrid Solids. Eur. J. Inorg. Chem. 2013, 11491156.

(27) Duval, S.; Floquet, S.; Simonnet-Jégat, C.; Marrot, J.; Biboum, R. N.; Keita, B.; Nadjo, L.; Haouas, M.; Taulelle, F.; Cadot, E. Capture of the $\left[\mathrm{Mo}_{3} \mathrm{~S}_{4}\right]^{4+}$ Cluster within a $\left\{\mathrm{Mo}_{18}\right\}$ Macrocycle Yielding a Supramolecular Assembly Stabilized by a Dynamic H-Bond Network. J. Am. Chem. Soc. 2010, 132, 2069-2077.

(28) Müller, A.; Fedin, V. P.; Kuhlmann, C.; Bögge, H.; Hauptfleisch, B.; Fedin, V. P.; Fenske, H.-D.; Baum, G. "Adding" Stable Functional Complementary, Nucleophilic and Electrophilic Clusters: a Synthetic Route to $\left[\left\{\left(\mathrm{SiW}_{11} \mathrm{O}_{39}\right) \mathrm{Mo}_{3} \mathrm{~S}_{4}\left(\mathrm{H}_{2} \mathrm{O}\right)_{3}(\mu\right.\right.$ - 
$\left.\mathrm{OH})\}_{2}\right]^{10-}$ and $\left[\left\{\left(\mathrm{P}_{2} \mathrm{~W}_{17} \mathrm{O}_{61}\right) \mathrm{Mo}_{3} \mathrm{~S}_{4}\left(\mathrm{H}_{2} \mathrm{O}\right)_{3}(\mu-\mathrm{OH})\right\}_{2}\right]^{14-}$ as Examples. Chem. Commun. 1999, 1189-1190.

(29) Duval, S.; Pilette, M.-A.; Marrot, J.; Simonnet-Jégat, C.; Sokolov, M.; Cadot, E. Selective Inclusion of $\mathrm{Cu}^{+}$and $\mathrm{Ag}^{+}$ElectronRich Metallic Cations within Supramolecular Polyoxometalates Based on $\left\{\mathrm{AsW}_{9} \mathrm{O}_{33}\right\}\left\{\mathrm{Mo}_{3} \mathrm{~S}_{4}\right\}$ Combinations. Chem.-Eur. J. 2008, 14, 3457-3466.

(30) Sadakane, M.; Steckhan, E. Electrochemical Properties of Polyoxometalates as Electrocatalysts. Chem. Rev. 1998, 98, 219-238.

(31) Ueda, T. Electrochemistry of Polyoxometalates: From Fundamental Aspects to Applications. ChemElectroChem 2018, 5, 823-838.

(32) Hernández-Molina, R.; Sokolov, M.; Clegg, W.; Esparza, P.; Mederos, A. Preparation and Characterization of Triangular Clusters $\left[\mathrm{M}_{3} \mathrm{Q}_{4}(\mathrm{acac})_{3}(\mathrm{py})_{3}\right]^{+}(\mathrm{M}=\mathrm{Mo}, \mathrm{W} ; \mathrm{Q}=\mathrm{S}, \mathrm{Se})$. Inorg. Chim. Acta 2002, $331,52-58$.

(33) Thouvenot, R.; Fournier, M.; Franck, R.; RocchiccioliDeltcheff, C. Vibrational Investigations of Polyoxometalates. 3. Isomerism in Molybdenum(VI) and Tungsten(VI) Compounds related to the Keggin Structure. Inorg. Chem. 1984, 23, 598-605.

(34) Rocchiccioli-Deltcheff, C.; Thouvenot, R. Vibrational Studies of Heteropolyanions related to $\alpha-\mathrm{P}_{2} \mathrm{~W}_{18} \mathrm{O}_{62}{ }^{6-}$-I- Infrared Evidence of the Structure of $\alpha-1$ and $\alpha 2-\mathrm{P}_{2} \mathrm{~W}_{17} \mathrm{O}_{61}{ }^{10-}$. Spectrosc. Lett. 1979, 12, 127138.

(35) Chen, Y.-G.; Gong, J.; Qu, L.-Y. Tungsten-183 Nuclear Magnetic Resonance Spectroscopy in the Study of Polyoxometalates. Coord. Chem. Rev. 2004, 248, 245-260.

(36) Jaramillo, T. F.; Bonde, J.; Zhang, J.; Ooi, B.-L.; Andersson, K.; Ulstrup, J.; Chorkendorff, I. Hydrogen Evolution on Supported Incomplete Cubane-type $\left[\mathrm{Mo}_{3} \mathrm{~S}_{4}\right]^{4+}$ Electrocatalysts. J. Phys. Chem. C 2008, 112, 17492-17498.

(37) Tran, P. D.; Tran, T. V.; Orio, M.; Torelli, S.; Truong, Q. D.; Nayuki, K.; Sasaki, Y.; Chiam, S. Y.; Yi, R.; Honma, I.; Barber, J.; Artero, V. Coordination Polymer Structure and Revisited Hydrogen Evolution Catalytic Mechanism for Amorphous Molybdenum Sulfide. Nat. Mater. 2016, 15, 640-646.

(38) Kristensen, J.; Zhang, J.; Chorkendorff, I.; Ulstrup, J.; Ooi, B. L. Assembled Monolayers of $\mathrm{Mo}_{3} \mathrm{~S}_{4}{ }^{4+}$ Clusters on Well-Defined Surfaces. Dalton Trans. 2006, 3985-3990.

(39) Duval, S.; Floquet, S.; Simonnet-Jégat, C.; Marrot, J.; Biboum, R. N.; Keita, B.; Nadjo, L.; Haouas, M.; Taulelle, F.; Cadot, E. Capture of the $\left[\mathrm{Mo}_{3} \mathrm{~S}_{4}\right]^{4+}$ Cluster within a $\left\{\mathrm{Mo}_{18}\right\}$ Macrocycle Yielding a Supramolecular Assembly Stabilized by a Dynamic H-Bond Network. J. Am. Chem. Soc. 2010, 132, 2069-2077.

(40) Benck, J. D.; Hellstern, T. R.; Kibsgaard, J.; Chakthranont, P.; Jaramillo, T. F. Catalyzing the Hydrogen Evolution Reaction (HER) with Molybdenum Sulfide Nanomaterials. ACS Catal. 2014, 4, 39573971.

(41) Kibsgaard, J.; Jaramillo, T. F.; Besenbacher, F. Building an appropriate active-site motif into a hydrogen-evolution catalyst with thiomolybdate $\left[\mathrm{Mo}_{3} \mathrm{~S}_{13}\right]^{2-}$ clusters. Nat. Chem. 2014, 6, 248-253.

(42) Du, K.; Zheng, L.; Wang, T.; Zhuo, J.; Zhu, Z.; Shao, Y.; Li, M. Electrodeposited $\mathrm{Mo}_{3} \mathrm{~S}_{13}$ Films from $\left(\mathrm{NH}_{4}\right)_{2} \mathrm{Mo}_{3} \mathrm{~S}_{13} \cdot 2 \mathrm{H}_{2} \mathrm{O}$ for Electrocatalysis of Hydrogen Evolution Reaction. ACS Appl. Mater. Interfaces 2017, 9, 18675-18681.

(43) Wang, H.; Lu, Z.; Kong, D.; Sun, J.; Hymel, T. M.; Cui, Y. Electrochemical Tuning of $\mathrm{MoS}_{2}$ Nanoparticles on Three-Dimensional Substrate for Efficient Hydrogen Evolution. ACS Nano 2014, 8, 4940-4947.

(44) Li, D. J.; Maiti, U. N.; Lim, J.; Choi, D. S.; Lee, W. J.; Oh, Y.; Lee, G. Y.; Kim, S. O. Molybdenum Sulfide/N-Doped CNT Forest Hybrid Catalysts for High-Performance Hydrogen Evolution Reaction. Nano Lett. 2014, 14, 1228-1233.

(45) Li, Y.; Wang, H.; Xie, L.; Liang, Y.; Hong, G.; Dai, H. MoS Nanoparticles Grown on Graphene: An Advanced Catalyst for the Hydrogen Evolution Reaction. J. Am. Chem. Soc. 2011, 133, 72967299.

(46) Laursen, A. B.; Vesborg, P. C. K.; Chorkendorff, I. A HighPorosity Carbon Molybdenum Sulphide Composite with Enhanced
Electrochemical Hydrogen Evolution and Stability. Chem. Commun. 2013, 49, 4965-4967.

(47) Dominey, R. N.; Lewis, N. S.; Bruce, J. A.; Bookbinder, D. C.; Wrighton, M. S. Improvement of Photoelectrochemical Hydrogen Generation by Surface Modification of p-Type Silicon Semiconductor Photocathodes. J. Am. Chem. Soc. 1982, 104, 467-482.

(48) Baltrusaitis, J.; Mendoza-Sanchez, B.; Fernandez, V.; Veenstra, R.; Dukstiene, N.; Roberts, A.; Fairley, N. Generalized Molybdenum Oxide Surface Chemical State XPS Determination via Informed Amorphous Sample Model. Appl. Surf. Sci. 2015, 326, 151-161.

(49) Merki, D.; Fierro, S.; Vrubel, H.; Hu, X. Amorphous Molybdenum Sulfide Films as Catalysts for Electrochemical Hydrogen Production in Water. Chem. Sci. 2011, 2, 1262-1267.

(50) Weber, T.; Muijsers, J. C.; Niemantsverdriet, J. W. Structure of Amorphous $\mathrm{MoS}_{3}$. J. Phys. Chem. 1995, 99, 9194-9200.

(51) Souza, A. L.; Filho, G. T.; Kubota, L. T.; Mendes, R. K.; Botelho do Rego, A. M.; Oliveira, O. N., Jr.; de Villeneuve, C. H.; Chazalviel, J. N.; Allongue, P.; Ozanam, F.; Filho, U. P. R. Poly(Dimethylsiloxane) as a Pre-Coating in Layer-by-Layer Films Containing Phosphotungstate Nanoclusters Electrochemically Sensitive Toward s-Triazines. RSC Adv. 2014, 4, 29612-29621.

(52) Yi, Z.-H.; Cui, X.-B.; Zhang, X.; Chen, Y.; Xu, J.-Q.; Yang, G.D.; Liu, Y.-B.; Yu, X.-Y.; Yu, H.-H.; Duan, W.-J. A Novel 2D Layer Structural Compound Constructed from Tetra-Capped PseudoKeggin Heteropolytungstates Interacting with Copper Coordination Fragments: Inorg. Chem. Commun. 2007, 10, 1448-1452.

(53) Chen, W.-C.; Li, H.-L.; Wang, X.-L.; Shao, K.-Z.; Su, Z.-M.; Wang, E.-B. Assembly of Cerium(III)-Stabilized Polyoxotungstate Nanoclusters with $\mathrm{SeO}_{3}{ }^{2-} / \mathrm{TeO}_{3}{ }^{2-}$ Templates: From Single Polyoxoanions to Inorganic Hollow Spheres in Dilute Solution. Chem.Eur. J. 2013, 19, 11007-11015.

(54) Shibahara, T.; Tsuru, H.; Kuroya, H. XPS Spectra of Incomplete Cubane-type Cluster with $\mathrm{Mo}_{3} \mathrm{O}_{4-n} \mathrm{~S}_{\mathrm{n}}{ }^{4+}$ Core $(\mathrm{n}=0-$ 4). Inorg. Chim. Acta 1988, 150, 167-168.

(55) Chatt, J.; Elson, C. M.; Leigh, G. J.; Connor, J. A. X-Ray Photoelectron Emission Studies of Some Complexes of Molybdenum in Formal Oxidation States of III, IV, V, and VI. J. Chem. Soc., Dalton Trans. 1976, 1351-1354.

(56) Halada, G. P.; Clayton, C. R. Comparison of Mo-N and W-N Synergism during Passivation of Stainless Steel through X-Ray Photoelectron Spectroscopy and Electrochemical Analysis. J. Vac. Sci. Technol., A 1993, 11, 2342-2347.

(57) Cicero, R. L.; Linford, M. R.; Chidsey, C. E. D. Photoreactivity of Unsaturated Compounds with Hydrogen-Terminated Silicon(111). Langmuir 2000, 16, 5688-5695.

(58) Zhang, X. G. Electrochemistry of Silicon and Its Oxide; Kluwer Academic: New York, 2001; p 47.

(59) Loget, G.; Padilha, J.; Martini, E.; Desouza, M.; Desouza, R. Efficiency and Stability of Transition Metal Electrocatalysts for the Hydrogen Evolution Reaction using Ionic Liquids as Electrolytes. Int. J. Hydrogen Energy 2009, 34, 84-90.

(60) Boudart, M. Turnover Rates in Heterogeneous Catalysis. Chem. Rev. 1995, 95, 661-666.

(61) Costentin, C.; Drouet, S.; Robert, M.; Savéant, J.-M. Turnover Numbers, Turnover Frequencies, and Overpotential in Molecular Catalysis of Electrochemical Reactions. Cyclic Voltammetry and Preparative-Scale Electrolysis. J. Am. Chem. Soc. 2012, 134, 1123511242.

(62) Hellstern, T. R.; Kibsgaard, J.; Tsai, C.; Palm, D. W.; King, L. A.; Abild-Pedersen, F.; Jaramillo, T. F. Investigating Catalyst-Support Interactions To Improve the Hydrogen Evolution Reaction Activity of Thiomolybdate $\left[\mathrm{Mo}_{3} \mathrm{~S}_{13}\right]^{2-}$ Nanoclusters. ACS Catal. 2017, 7, 71267130.

(63) Jaramillo, T. F.; Jorgensen, K. P.; Bonde, J.; Nielsen, J. H.; Horch, S.; Chorkendorff, I. Identification of Active Edge Sites for Electrochemical $\mathrm{H}_{2}$ Evolution from $\mathrm{MoS}_{2}$ Nanocatalysts. Science 2007, 317, 100-102. 
(64) Khusnutdinova, D.; Beiler, A. M.; Wadsworth, B. L.; Jacob, S. I.; Moore, G. F. Metalloporphyrin-Modified Semiconductors for Solar Fuel Production. Chem. Sci. 2017, 8, 253-259.

(65) Gu, J.; Yan, Y.; Young, J. L.; Steirer, K. X.; Neale, N. R.; Turner, J. A. Water Reduction by a p-GaInP ${ }_{2}$ Photoelectrode Stabilized by an Amorphous $\mathrm{TiO}_{2}$ Coating and a Molecular Cobalt Catalyst. Nat. Mater. 2016, 15, 456-460.

(66) Jürgensen, A.; Moffat, J. B. The Stability of 12-Molybdosilicic, 12-Tungstosilicic, 12-Molybdophosphoric and 12-Tungstophosphoric Acids in Aqueous Solution at Various pH. Catal. Lett. 1995, 34, 237244.

(67) Madou, M. J.; Loo, B. H.; Frese, K. W.; Morrison, S. R. Bulk and Surface Characterization of the Silicon Electrode. Surf. Sci. 1981, $108,135-152$.

(68) Hellstern, T. R.; Benck, J. D.; Kibsgaard, J.; Hahn, C.; Jaramillo, T. F. Engineering Cobalt Phosphide (CoP) Thin Film Catalysts for Enhanced Hydrogen Evolution Activity on Silicon Photocathodes. Adv. Energy Mater. 2016, 6, 1501758.

(69) Sokolov, M. N.; Kalinina, I. V.; Peresypkina, E. V.; Cadot, E.; Tkachev, S. V.; Fedin, V. P. Incorporation of Molybdenum Sulfide Cluster Units into a Dawson-Like Polyoxometalate Structure To Give Hybrid Polythiooxometalates. Angew. Chem., Int. Ed. 2008, 47, 14651468.

(70) Cadot, E.; Sokolov, M. N.; Fedin, V. P.; Simonnet-Jégat, C.; Floquet, S.; Sécheresse, F. A Building Block Strategy to Access SulfurFunctionalized Polyoxometalate based Systems using $\left\{\mathrm{Mo}_{2} \mathrm{~S}_{2} \mathrm{O}_{2}\right\}$ and $\left\{\mathrm{Mo}_{3} \mathrm{~S}_{4}\right\}$ as Constitutional Units, Linkers or Templates. Chem. Soc. Rev. 2012, 41, 7335-7353.

(71) Shibahara, T.; Yamasaki, M.; Sakane, G.; Minami, K.; Yabuki, T.; Ichimura, A. Syntheses and Electrochemistry of Incomplete Cubane-type Clusters with $\mathrm{M}_{3} \mathrm{~S}_{4}$ Cores ( $\mathrm{M}=$ Molybdenum, Tungsten). X-Ray Structures of $\left[\mathrm{W}_{3} \mathrm{~S}_{4}\left(\mathrm{H}_{2} \mathrm{O}\right)_{9}\right]$ $\left(\mathrm{CH}_{3} \mathrm{C}_{6} \mathrm{H}_{4} \mathrm{SO}_{3}\right)_{4} .9 \mathrm{H}_{2} \mathrm{O}, \mathrm{Na}_{2}\left[\mathrm{~W}_{3} \mathrm{~S}_{4}(\mathrm{Hnta})_{3}\right] .5 \mathrm{H}_{2} \mathrm{O}$, and $(\mathrm{bpyH})_{5}\left[\mathrm{~W}_{3} \mathrm{~S}_{4}(\mathrm{NCS})_{9}\right] .3 \mathrm{H}_{2} \mathrm{O}$. Inorg. Chem. 1992, 31, 640-647.

(72) Sheldrick, G. M. SADABS: Program for Scaling, Correction of Area Detector Data; University of Göttingen: Germany, 1997.

(73) Blessing, R. H. An Empirical Correction for Absorption Anisotropy. Acta Crystallogr. 1995, 51, 33-38.

(74) Sheldrick, G. M. SHELX-TL, version 5.03, Software Package for the Crystal Structure Determination; Siemens Analytical X-ray Instrument Division: Madison, WI USA, 1994. 